OBERDAN DE CASTRO

\title{
A RESPONSABILIDADE DO TOMADOR COMO MECANISMO DE PROTEÇÃO SOCIAL DO TRABALHADOR NA TERCEIRIZAÇÃO
}

Dissertação de Mestrado

Orientador: Professor Dr. Ari Possidonio Beltran

UNIVERSIDADE DE SÃO PAULO

FACULDADE DE DIREITO

SÃO PAULO - SP 




\title{
A RESPONSABILIDADE DO TOMADOR COMO MECANISMO DE PROTEÇÃO SOCIAL DO TRABALHADOR NA TERCEIRIZAÇÃO
}

\begin{abstract}
Dissertação apresentada à Banca Examinadora do Programa de Pós-Graduação em Direito, da Faculdade de Direito da Universidade de São Paulo, como exigência parcial para obtenção do título de Mestre em Direito, na área de concentração Direito do Trabalho e da Seguridade Social, sob a orientação do Professor Dr. Ari Possidonio Beltran.
\end{abstract}

UNIVERSIDADE DE SÃO PAULO

FACULDADE DE DIREITO

SÃO PAULO - SP 


\section{Catalogação na Publicação}

\section{Serviço de Processos Técnicos da Biblioteca da}

\section{Faculdade de Direito da Universidade de São Paulo}

\section{Castro, Oberdan de}

A responsabilidade do tomador como mecanismo de proteção social do trabalhador na terceirização / Oberdan de Castro. -- São Paulo, 2019. 138 p. ; $30 \mathrm{~cm}$

Dissertação (Mestrado) - Programa de Pós-Graduação em Direito, Faculdade de Direito, Universidade de São Paulo, São Paulo, 2019.

Orientador: Ari Possidonio Beltran.

1. Direito do Trabalho. 2. Terceirização. 3. Responsabilidade. 4. Proteção. 5. Legislação, Brasil. I. Beltran, Ari Possidonio, orient. II. Título. 


\section{RESUMO}

CASTRO, Oberdan de. A responsabilidade do tomador como mecanismo de proteção social do trabalhador na terceirização. 2019. 138 p. Dissertação (Mestrado) - Faculdade de Direito, Universidade de São Paulo, São Paulo, 2019.

A globalização, o avanço da tecnologia e o acirramento da concorrência internacional contribuíram com uma busca incessante pela redução de custos, disseminando pelo mundo práticas flexibilizadoras para otimização do processo produtivo. Destaca-se a fragmentação da produção com a concentração no core business e a delegação de parte das atividades empresariais a terceiros, fenômeno ao qual se denominou terceirização. Proporcionalmente à expansão da terceirização, houve um recrudescimento de práticas fraudulentas, e o surgimento de empresas inidôneas, sem suporte econômico, que passaram a atuar no ramo. Neste contexto, com a diluição do risco da atividade a várias pessoas físicas e jurídicas que se imiscuem, o trabalhador muitas vezes não sabe nem ao menos a quem recorrer, tendo, assim, violados direitos essenciais tão consagrados outrora em nosso Estado Democrático de Direito. Para fazer frente a esse crescente desequilíbrio entre o capital e o trabalho, tornou-se necessário pesquisar a fundo os mecanismos para o combate à precarização das relações de trabalho. E a responsabilidade se mostrou como um dos instrumentos de realização de Justiça Social e tutela de direitos fundamentais do trabalhador.

Palavras-chave: Direito do trabalho; terceirização; responsabilidade, proteção. 


\begin{abstract}
CASTRO, Oberdan de. The responsibility of the service user as mechanism of social protection of the worker. 2019. 138 p. Dissertation (Master) - Faculty of Law, University of São Paulo, São Paulo, 2019.

The globalization, the advancement of technology and the intensification of international competition have contributed to an incessant search for cost reduction, disseminating throughout the world flexible practices to optimize the production process. Of note is the fragmentation of production with concentration on the core business and the delegation of part of the business activities to third parties, a phenomenon that was termed outsourcing. In proportion to the expansion of outsourcing, there was a resurgence of fraudulent practices, and the emergence of insidious companies, without economic support, that started to operate in the branch. In this context, by diluting the risk of the activity to various individuals and legal entities who are involved, the worker often does not know at least who to turn to, thus having violated essential rights so long established in our Democratic State of Law. In order to deal with this growing imbalance between capital and labor, it became necessary to thoroughly investigate mechanisms for combating the precariousness of labor relations. And responsibility has proved to be one of the tools for achieving Social Justice and safeguarding the fundamental rights of the worker.
\end{abstract}

Keywords: Labor law; outsourcing; responsibility; protection. 


\section{SUMÁRIO}

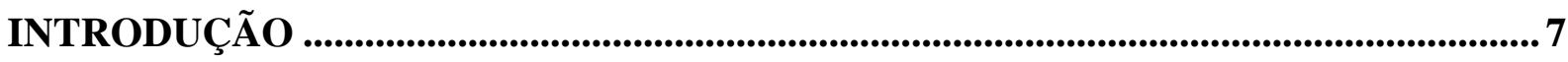

1. TERCEIRIZAÇÃO - CONTEXTO HISTÓRICO ...................................................... 11

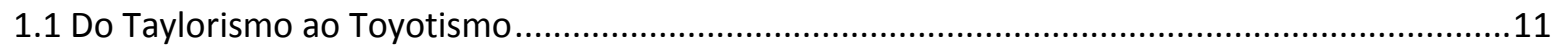

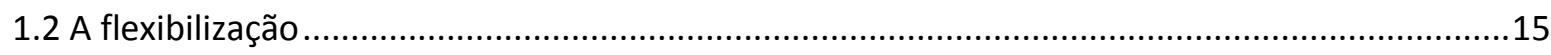

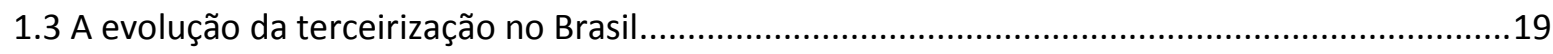

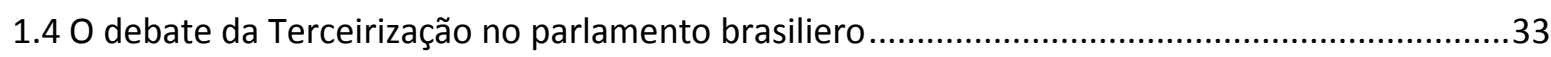

1.5 AS perspectivas face à recente regulamentação da terceirização.............................................37

2. TERCEIRIZAÇÃO - NOÇÕES GERAIS............................................................................... 43

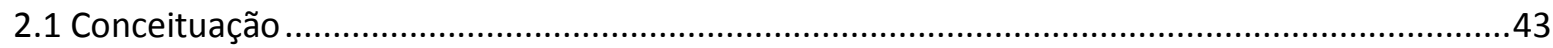

2.2 A terceirização, o marchandage, a subempreitada e o contrato temporário...............................46

2.3 A terceirização e outras formas de contratação .......................................................................50

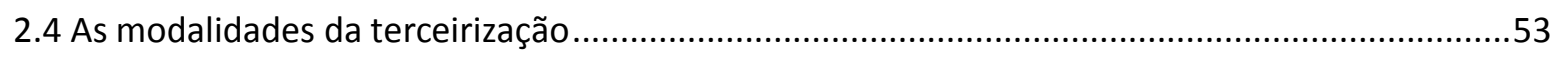

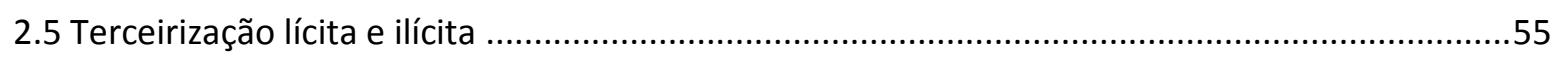

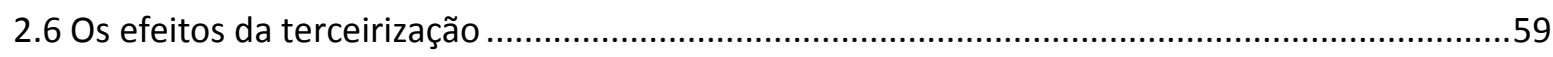

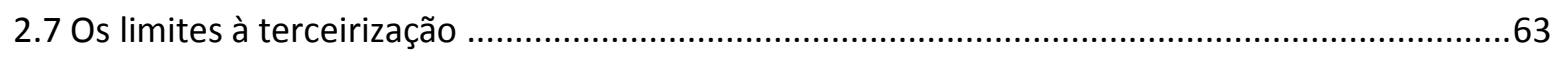

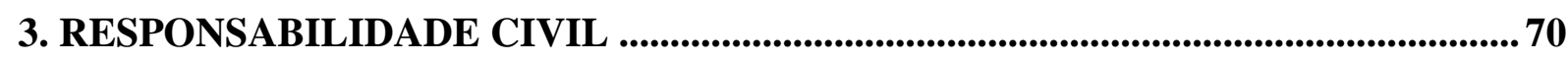

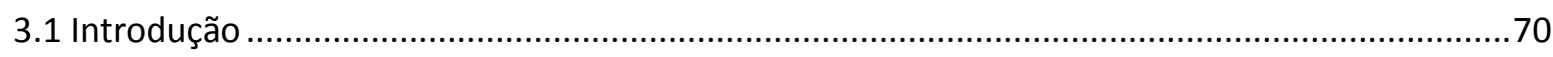

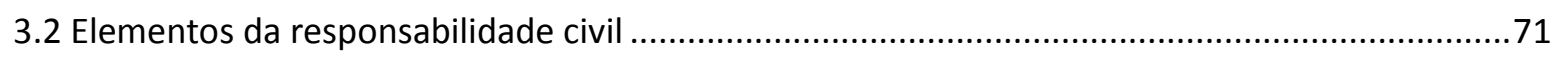

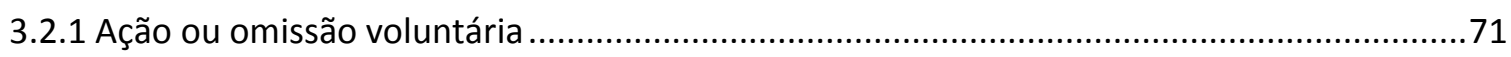

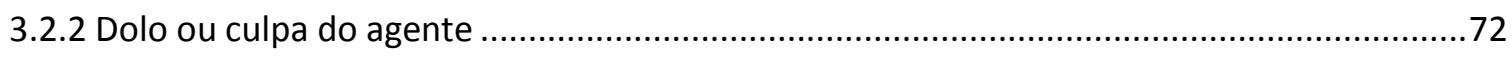

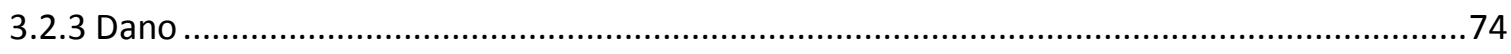

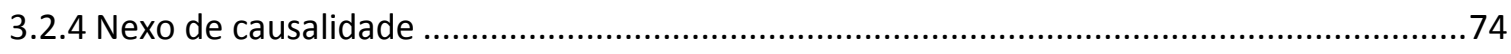

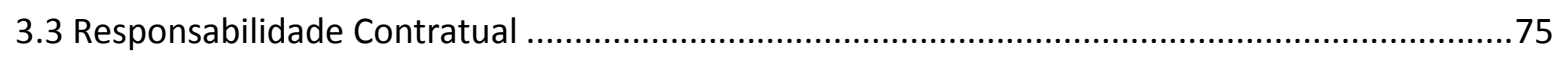

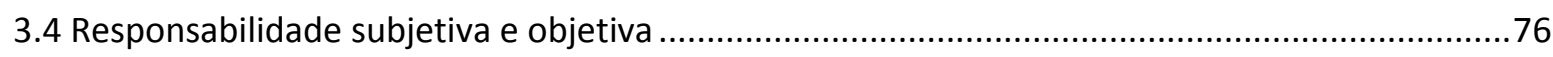

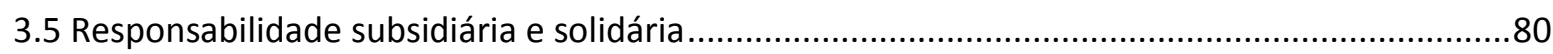

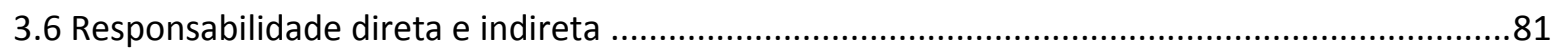

4. RESPONSABILIDADE NO TOMADOR NA TERCEIRIZAÇÃO............................... 84

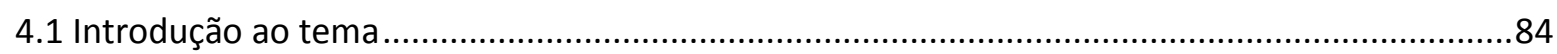

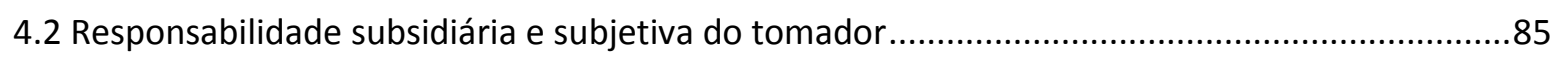

4.3 Responsabilidade solidária e objetiva do tomador .....................................................................90 
4.4 A análise processual da responsabilidade do tomador 97

4.5 A responsabilidade do tomador pela saúde do trabalhador terceirizado. 99

4.6 A responsabilidade do tomador no âmbito da América Latina 105

CONSIDERAÇÕES FINAIS ....................................................................................................109

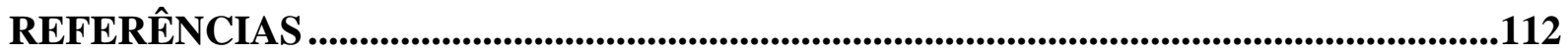

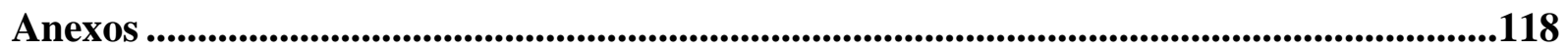

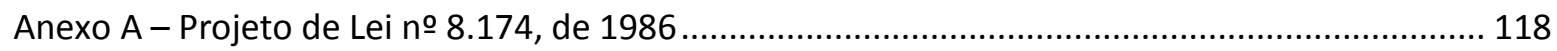

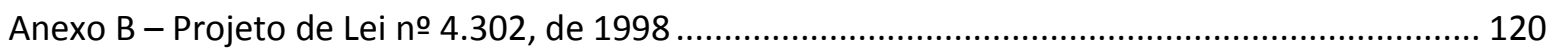

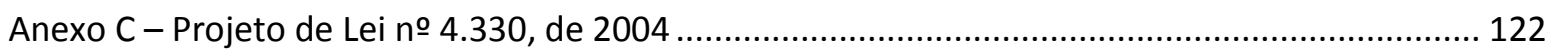

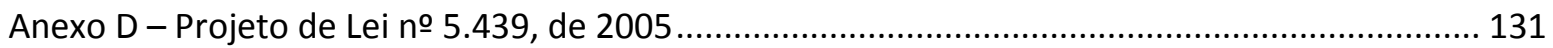

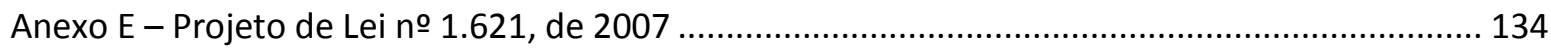




\section{INTRODUÇÃO}

O mundo vivenciou intensas transformações sociais, políticas e econômicas nos últimos anos. O capital financeiro internacional assumiu o papel determinante dos contornos do mercado, acirrando a concorrência, também alimentada pelo avanço da tecnologia e a larga utilização da robótica.

A concorrência desenfreada acabou por contribuir com a famigerada busca pela redução de custos objetivando a sobrevivência empresarial na nova política de mercado. As despesas trabalhistas são apontadas como as maiores responsáveis pelo enfraquecimento do poder de competitividade de uma empresa no cenário mercantil.

Na mesma toada, a disseminação do neoliberalismo afrouxou as rédeas do Estado sobre a economia. A flexibilização das leis trabalhistas acarretou o que a doutrina denominou de precarização das relações de trabalho. O modelo toyotista de fragmentação do processo produtivo, com a delegação de etapas da produção a outras empresas, se disseminou na economia com a terceirização. E o fenômeno vem crescendo exponencialmente, em especial no Brasil. Segundo o Dieese, o Brasil tem 12 milhões de trabalhadores terceirizados, 26,8\% do número total de empregados que possuem carteira de trabalho assinada ${ }^{1}$.

Por outro lado, no Brasil, a evolução do fenômeno, a princípio, não foi acompanhada por uma legislação que regulamentasse satisfatoriamente suas implicações. A Consolidação das Leis Trabalhistas, de 1943, trata apenas de duas formas de subcontratação de mão-de-obra, a empreitada e a subempreitada. Não obstante o surgimento posterior de algumas leis a tratar, ainda de forma tímida, a terceirização, como o Decreto-lei no 200/67, que regulamentou sua aplicação a algumas atividades do setor público, e posteriormente a Lei ${ }^{\circ} 7.102 / 83$, ao tratar

\footnotetext{
1 Secretaria. Nacional de Relações de Trabalho e Departamento Intersindical de Estatística e Estudos Socioeconômicos. Terceirização e desenvolvimento: uma conta que não fecha. Dossiê acerca do impacto da terceirização sobre os trabalhadores e propostas para garantir a igualdade de direitos. São Paulo: Central Única dos Trabalhadores, 2014, p. 13.
} 
das empresas exploradoras do serviço de vigilância e transporte de valores, bem como a Lei $\mathrm{n}^{\circ}$ 6.019/74, que dispôs sobre o trabalho temporário, é certo que a abordagem do tema somente ganhou maior amplitude com a consolidação de entendimento jurisprudencial pelo Tribunal Superior do Trabalho.

Por muitos anos a questão era resolvida através da Súmula 331 do C. TST. Até que o cenário de mudanças do quadro político brasileiro e a tendência reformista do governo de Michel Temer, que assumiu a Presidência da República em 2.016, propiciaram o desarquivamento de um projeto de lei enviado ao Congresso Nacional há quase vinte anos, o que resultou na promulgação, em 31 de março de 2.017, da Lei $n^{\circ} 13.429 / 2017$, que, dentre outras medidas, acrescentou o artigo $5^{\circ}$-A a Lei $n^{\circ} 6.019 / 74$, passando a regulamentar o instituto da terceirização. A grande celeuma provocada pela novel legislação foi a previsão vaga utilizada pelo legislador ao se referir aos contratos de prestação de "serviços determinados e específicos". Não houve como se aferir se a intenção do legislador, com tal redação, era de permitir a terceirização das chamadas "atividades-fim" das empresas. Diante disso, a famigerada Reforma Trabalhista (Lei $\mathrm{n}^{\circ}$ 14.467/2017), publicada em 13 de julho de 2017, menos de quatro meses após a lei anterior, tornou a alterar a Lei $n^{\circ}$ 6.019/74. Com a novel redação, poderão ser terceirizadas as atividades-fim da empesa tomadora. Para os fins da presente pesquisa, o artigo $5^{\circ}$-A estabeleceu a responsabilização subsidiária da tomadora $\left(\S 5^{\circ}\right)$, ora denominada contratante, pelas obrigações trabalhistas referentes ao período da prestação dos serviços.

Ocorre que, proporcionalmente à expansão da terceirização, observa-se uma intensificação do cometimento de fraudes, com o surgimento de empresas inidôneas, sem suporte econômico, que passam a atuar no ramo. Neste contexto, o trabalhador passa a ser a maior vítima, tendo violados direitos essenciais tão consagrados outrora em nosso Estado Democrático de Direito, que tem como fundamentos a valorização do trabalho e a proteção do trabalhador.

Diante de tal premissa, tornou-se necessário pesquisar a fundo os mecanismos de efetiva responsabilização de cada um dos envolvidos no processo de exploração da mão-deobra, visando à proteção dos direitos básicos do trabalhador. 
Seria a responsabilidade solidária e objetiva, ao invés da responsabilidade subsidiária e subjetiva, o meio eficaz para harmonização da relação entre capital e trabalho frente à terceirização? Em sede preliminar, a resposta parece ser afirmativa. Obrigar o trabalhador a aguardar que se esgotem todos os meios de execução em face da empresa terceirizada para somente a partir daí poder acionar a empresa contratante, tomadora e beneficiária dos serviços prestados, dificulta e algumas vezes inviabiliza o recebimento do crédito trabalhista. A responsabilidade objetiva e solidária seria um mecanismo de garantir os direitos do trabalhador, de natureza alimentar, conferindo efetividade, simplicidade e celeridade à execução. Além disso, observa-se o caráter didático na imputação de tal responsabilidade à contratante tomadora, no sentido de que a terceirização do processo produtivo seja realizada de maneira responsável, incentivando a empresa contratante a verificar a idoneidade da empresa terceirizada e a exigir garantias de cumprimento dos deveres trabalhistas. Assim, a responsabilidade objetiva e solidária proporcionaria um desestímulo à utilização de meios que propiciam o cometimento de fraudes e, por consequência, a precarização das relações trabalhistas. Contudo, o que se verifica é toda uma resistência à aplicação da responsabilidade objetiva e solidária na terceirização, motivada pelos interesses do poder econômico.

No cenário atual, diante da recente promulgação das Leis $n^{\circ} 13.429 / 2017$ e $n^{\circ}$ 13.467/2017, necessária se faz uma reflexão sobre qual mecanismo de responsabilização dos agentes envolvidos se mostra mais eficaz tendo como premissa os valores sociais do trabalho e a dignidade da pessoa humana, fundamentos da República Federativa do Brasil.

O presente trabalho vem discutir, assim, a necessidade e a importância da responsabilidade do contratante tomador no âmbito da terceirização, como meio de realização de Justiça Social e tutela de direitos fundamentais do trabalhador.

Aplicar-se-á o método histórico, na delimitação do contexto histórico da economia para exposição da problemática. O método qualitativo será utilizado para tratar da responsabilidade no âmbito da terceirização do processo produtivo. O método indutivo se fará presente na tentativa de se apontar soluções para o problema exposto. Utilizar-se-á também o método qualitativo ao se coligir as diversas posições doutrinárias e jurisprudenciais a respeito do assunto. 
O trabalho adotará a pesquisa exploratória, mediante análise de material bibliográfico, documental e jurisprudencial. 


\section{CONSIDERAÇÕES FINAIS}

O presente trabalho demonstrou que o processo da terceirização no Brasil alcançou consideráveis proporções sem uma correspondente regulamentação por parte de nosso legislador, o que acarretou o cometimento de abusos, levando a jurisprudência a criar mecanismos visando controlar as anomalias do fenômeno.

Após o surgimento de algumas leis esparsas regulamentando situações específicas, mas de maneira tímida, e o amadurecimento da jurisprudência brasileira através do Enunciado 256 e a Súmula 331 do C. Tribunal Superior do Trabalho, foram promulgadas as Leis $\mathrm{n}^{\circ}$ 13.427/2017 e 13.467/2017, que finalmente regulamentaram efetivamente o instituto da terceirização.

De fato, o processo terceirizante está ligado à flexibilização, com a descentralização da produção, a concentração no core business e a delegação de parte das atividades empresariais para terceiros, que, por especializados, reúnem mais condições de realizá-las por um custo menor. No entanto, as recém promulgadas leis acabaram por permitir a terceirização inclusive na atividade principal da empresa, o que escancara seu objetivo primordial, que é a mera redução de custos, doa a quem doer, e não o verdadeiro aprimoramento do processo produtivo e indiretamente tal redução de custos, com ganho de competitividade no mercado e aumento dos lucros.

Infelizmente a redução dos custos, doa a quem doer, vem acompanhada do comprometimento de direitos essenciais do trabalhador, relacionados à sua própria dignidade. A terceirização irrestrita em um cenário predominantemente liberal dá margem para a burla e fraude na aplicação das normas trabalhistas. Em muitas ocasiões, mesmo sendo legal a terceirização, dentro da nova ordem jurídica, deve ser empreendida por uma empresa que reúna capacidade econômica compatível com a sua execução, nos exatos termos da lei, sob pena de se desvirtuar totalmente para uma mera intermediação de mão de obra. E conforme os primados fundamentais de Direito Internacional do Trabalho, o trabalho humano não é simples mercadoria de comércio. 
A relação de emprego clássica ainda continua a regra geral estabelecida pelo nosso ordenamento jurídico, consubstanciada nos artigos $2^{\circ}$, caput, e $3^{\circ}$ da CLT, mantidos integralmente pelas recentes reformas. Por isso, não obstante a autorização legislativa para a terceirização irrestrita, é certo que se entre o empregado da empresa de prestação de serviços a terceiros e a empresa contratante for constatada a presença dos requisitos da relação de emprego, poderá haver o reconhecimento judicial do liame empregatício, baseado no art. $9^{\circ}$ da CLT.

E a responsabilidade das partes envolvidas indubitavelmente é o mecanismo primordial na busca pela harmonização da relação entre o capital e o trabalho frente à terceirização. Em que pese a solução legislativa apresentada pela recente legislação no sentido de imputar a responsabilidade subsidiária da empresa tomadora dos serviços, que lhe garante o benefício de ordem, é certo que não parece razoável obrigar o trabalhador a aguardar que se esgotem todos os meios de execução em face da empresa terceirizada para somente a partir daí poder acionar a empresa contratante, beneficiária dos serviços prestados. Ora, o crédito trabalhista tem natureza alimentar e de urgente tutela e não pode se submeter à perfumaria processual criada por um arcabouço legislativo, que algumas vezes, até mesmo inviabiliza o seu recebimento.

Nesse contexto, por simples hermenêutica, a partir da nova legislação, que expressamente consagra a responsabilidade subsidiária do tomador, é possível se entender que, se caracterizada a fraude na utilização do instituto, ao invés da mera responsabilidade subsidiária, à tomadora se atribui a responsabilidade principal por todas as obrigações (artigo $9^{\circ}$ da CLT c/c artigo 942, parágrafo único, do Código Civil). E as situações são encontradas na própria Lei n ${ }^{\circ}$ 6.019/74: quando na execução da atividade a empresa prestadora não exerça com exclusividade a direção do trabalho de seus empregados (artigo $4^{\circ}$-A, $\S 1^{\circ}$, da Lei $n^{\circ} 6.019 / 74$ ), quando a empresa tomadora exija e a prestadora realize atividade distinta da prevista no contrato de prestação de serviço (artigo $5^{\circ}-\mathrm{A}, \S 1^{\circ}$, da Lei $\mathrm{n}^{\circ}$ 6.019/74) ou quando a empresa prestadora não possua capacidade econômica compatível com a execução do contrato (artigo $4^{\circ}$-A caput, da Lei $n^{\circ}$ 6.019/1974), a ser verificada tanto no momento da contratação quanto da execução contratual. 
Por outro lado, fazendo uma análise mais aprofundada, tendo como referência uma nova ordem axiológica trazida pela Constituição Federal de 1988, que não interpreta disposições legais apenas considerando o texto da norma, mas buscando a essência e os valores nela depositados, tendo como referência todo o arcabouço jurídico, é possível desconstituir a regra trazida pela novel legislação de mera responsabilidade subsidiária do tomador de serviços. A Constituição Federal de 1988 estatui, dentre seus preceitos, a dignidade da pessoa humana, os valores sociais do trabalho, o primado do trabalho, a função social da propriedade, a defesa do meio ambiente, inclusive do trabalho, a busca do pleno emprego. O Direito do Trabalho, como ramo autônomo, não apenas regula as relações laborais, mas estipula normas mínimas de caráter público e indisponível tendo como referência o interesse social que emana, inclusive, da Constituição Federal. Considerando que o trabalho humano é o objeto da relação laboral, torna imprescindível uma intervenção pública com vista a proteger o homem, impedindo que se torne mero meio de alcance dos objetivos econômicos. Com efeito, a análise da responsabilidade do tomador deve transcender do aspecto positivista para uma abordagem mais complexa do fenômeno da terceirização, sob a perspectiva do Direito do Trabalho como ramo autônomo e de natureza tuitiva.

Com efeito, é possível se entender pela responsabilidade solidária do tomador, tendo como norte interpretações aos artigos 942, parágrafo único, do Código Civil, $2^{\circ}$ da CLT, 421 do Codex Civil, 932, III, do Código Civil, 927, parágrafo único, também do Código Civil, e em relação aos danos ao meio ambiente do trabalho, considerando o art. $14, \S 1^{\circ}$, da Lei $n^{\circ}$ $6.938 / 1981$.

Celeumas à parte, é inequívoco que a imputação da responsabilidade ao tomador contribui para que a terceirização do processo produtivo ocorra de maneira responsável, incentivando a empresa contratante a verificar a idoneidade da empresa terceirizada e a exigir garantias de cumprimento dos deveres trabalhistas, proporcionando um desestímulo à utilização de meios que propiciem o cometimento de fraudes e precarizem as relações trabalhistas. Além disso, certo é que enquanto houver a amenização da responsabilidade do tomador de serviços para com os encargos trabalhistas do trabalhador terceirizado, persistirá o desvirtuamento do instituto da terceirização, com sua utilização apenas visando a redução de custos, doa a quem doer. 


\section{REFERÊNCIAS}

ALMEIDA, Renato Rua de. Eficácia dos direitos fundamentais nas relações de trabalho. Revista LTR. São Paulo, Ano 76, n. 06, p. 647-650, 2012.

ALVES, Amauri Cesar. Reforma Trabalhista, Terceirização e Critérios de Agregação do Trabalhador ao Sindicato. Revista LTr, ano 81, out. 2017, p. 1179.

BARROS, Alice Monteiro de (coordenadora). Curso de Direito do Trabalho. 5a. ed. São Paulo: LTR, 2007.

BELMONTE. Alexandre Agra. Curso de Responsabilidade Trabalhista: danos morais e patrimoniais nas relações de trabalho. 2a. ed. São Paulo: LTr, 2009.

BELTRAN, Ari Possidonio. A globalização e seus impactos nas relações de trabalho. Trabalho e Ambiente, v. 5, p. 9-41, 2007.

. Dilemas do Trabalho e do Emprego na Atualidade. São Paulo: LTr, 2001.

. Direito do Trabalho e direitos fundamentais. São Paulo: LTr, 2002.

. Direito do trabalho e economia na atualidade. Revista do Advogado (São Paulo). São Paulo, v. 26, n.6, p. 10-15, 2006.

. Flexibilização, globalização, terceirização e seus impactos nas relações do trabalho.

LTr: revista legislação do trabalho, São Paulo, v. 61, n.4, p. 490-495, 1997.

. Os novos rumos do direito do trabalho. Revista do Departamento de Direito do Trabalho e Seguridade Social da Faculdade de Direito da USP. São Paulo, ano 3, n. 5, p. 43-58, jul. 2008.

BOBBIO, Norberto. Teoria da norma jurídica. São Paulo: Edipro, 2001. 
CARELLI, Rodrigo de Lacerda. A responsabilidade do tomador de serviços na terceirização. LTr: revista legislação do trabalho, São Paulo, vol. 70, nº6, junho de 2006, p. 715.

CASSAR, Vólia Bomfim. Direito do Trabalho. 5a. ed. Niterói: Impetus, 2011.

CAVALIERI FILHO, Sérgio. Programa de Responsabilidade Civil. São Paulo: Atlas, 2008.

CORTEZ, Julpiano Chavez. Terceirização Trabalhista. São Paulo: LTr, 2015.

CUNHA, Tadeu Henrique Lopes da. Terceirização e seus efeitos sobre os direitos do trabalhador no ordenamento jurídico brasileiro. Dissertação de Mestrado. São Paulo: Faculdade de Direito da Universidade de São Paulo, 2007.

DALLEGRAVE NETO, José Affonso. Responsabilidade civil no direito do trabalho. São Paulo: LTr, 2017.

DAMASCENO, Fernando Américo Veiga. A locação de mão-de-obra e as empresas prestadoras de serviço. LTr: revista legislação do trabalho, São Paulo, v. 47, n. 11, p. 290-4, nov. 1983.

DA SILVA, Alessandro, KROST, Oscar, e SEVERO, Valdete Souto. "Fundamentos à responsabilidade solidária e objetiva da tomadora de serviços na "terceirização". Revista LTr, São Paulo, v. 75, n.1, p. 66-79, jan. 2011.

DELGADO, Maurício Godinho. Curso de Direito do Trabalho. 4a. ed. São Paulo: Ltr, 2005.

DINIZ, Maria Helena. Curso de Direito Civil Brasileiro: Direito de Empresa. Vol. 8, São Paulo: Saraiva, 2008.

DRUCK, Maria da Graça. Terceirização: (Des)Fordizando a fábrica - um estudo do complexo petroquímico da Bahia. Tese de Doutoramento, UNICAMP, Campinas: 1995. 
GASPAR, Danilo Gonçalves. Subordinação Potencial: encontrando o verdadeiro sentido da subordinação jurídica. São Paulo: LTr, 2016.

GIORDANI, Francisco Alberto M. P. Intermediação de mão-de-obra: uma leitura que leva à responsabilidade solidária entre as empresas prestadora e tomadora de serviços. LTr: revista legislação do trabalho, São Paulo, ano 72, $n^{\circ} 7$.

KELSEN, Hans. Teoria Pura do Direito. João Baptista Machado (trad.) São Paulo: Martins Fontes, 1998.

LACERDA, Luísa. Terceirização e intermediação de mão de obra: em busca de novos parâmetros de responsabilização. Revista do Tribunal Superior do Trabalho. São Paulo, v. 81, n. 3, p. 192-227, jul./set. 2015.

LEITÃO, Tábata Gomes Macedo de. A terceirização no contexto de eficácia dos direitos fundamentais. Dissertação de Mestrado. São Paulo: Faculdade de Direito da Universidade de São Paulo, 2012.

LOPES DE ANDRADE, Everaldo Gaspar. Princípios do Direito do Trabalho: Fundamentos teórico-filosóficos. São Paulo: LTr, 2008.

MAGANO, Octavio Bueno. Alcance e limites da terceirização no Direito do Trabalho. Noções atuais de direito do trabalho: estudos em homenagem ao professor Elson Gottschalk.

MARTINS, Sérgio Pinto. A terceirização e o direito do trabalho. 9. ed. São Paulo: Atlas, 2009. . Comentários à CLT. 14a. ed. São Paulo: Atlas, 2010. . Flexibilização das condições de trabalho. São Paulo: Editora Atlas, 2000.

MARX, Karl. O Capital: crítica da economia política. 22a. ed. Rio de Janeiro: Civilização Brasileira, 2008. 
NASCIMENTO, Amauri Mascaro. Curso de direito do trabalho. 24a. ed. São Paulo: Saraiva, 2009.

PIOVESAN, Georgia Patrignani Caldatto. Subcontratação como instrumento de violação ao princípio da proibição ao retrocesso social. Dissertação de Mestrado. São Paulo: Faculdade de Direito da Universidade de São Paulo, 2013.

PORTO, Lorena Vasconcelos; NIGRI, Fernanda (orgs.). Parassubordinação: homenagem ao Professor Márcio Túlio Viana. São Paulo: LTr, 2011, p. 183.

RENAULT, Luiz Otávio Linhares; MEDEIROS, Dárlen Prietsch. A Subordinação sem Derivações Semânticas. In: RENAULT, Luiz Otávio Linhares; CANTELLI, Paula Oliveira;

REQUIÃO, Rubens. Curso de Direito Comercial. Vol. 1. 25a. ed. São Paulo: Saraiva, 2003.

ROBORTELLA, Luiz Carlos Amorim. O moderno Direito do Trabalho. São Paulo: LTr, 1999. Terceirização - Aspectos Jurídicos - Responsabilidades - Direito Comparado. LTr: revista legislação do trabalho, São Paulo, vol. 58, nº 08, agosto de 1994, p. 938.

RUSSOMANO JUNIOR, Victor. Desregulamentação, flexibilização, ampla negociação, terceirização e atualização do direito do trabalho. Revista Magister de Direito do Trabalho. Porto Alegre, RS, v. 10, n. 60, p. 18-26, maio/jun., 2014.

SANTOS, Rodrigo Coimbra. Relações Terceirizadas de Trabalho. 22a. ed. Curitiba: Juruá, 2006.

SEVERINO, Antônio Joaquim. Metodologia do trabalho científico. 22a. ed. São Paulo: Cortez, 2004. 
SILVA, José Afonso da. Curso de Direito Constitucional Positivo. 13a. ed. São Paulo: Malheiros, 1997.

SOUTO MAIOR, Jorge Luiz. Curso de Direito do Trabalho: A relação de emprego. Vol. II. São Paulo: LTr, 2008.

A Responsabilidade Civil Objetiva do Empregador com Relação a Danos Pessoais e Sociais no âmbito das relações de trabalho. Revista Trabalhista - Direito e Processo, Rio de Janeiro, v. 12, p. 97-112, out./dez. 2004.

. Curso de Direito do Trabalho: Teoria geral do Direito do Trabalho, Vol. I: Parte I. São Paulo: LTr, 2011.

. Terceirização não pode ser usada para burlar direitos trabalhistas. Disponível em: <http://www.conjur.com.br/2004-jul-06/terceirizacao_nao_usada_burlar_direitos>. Acesso em: 03 julho.2017.

. Trabalho Descentralizado. A Terceirização sob uma Perspectiva Humanista. Revista Latinoamericana de Derecho Social, n. 9, 2009, pp. 159-174.

STOCO, Rui. Tratado de Responsabilidade Civil: doutrina e jurisprudência. 7a. ed. São Paulo: RT, 2007.

SÜSSEKIND, Arnaldo. Direito Constitucional do Trabalho. Rio de Janeiro: Renovar, 1999. . O Enunciado $n^{\circ}$ 256: mão-de-obra contratada e empresas de prestação de serviços. LTr: revista legislação do trabalho, São Paulo, v. 51, n. 3, março de 1987, p. 281.

VENOSA, Sílvio de Salvo. Direito Civil: Teoria Geral das Obrigações e Teoria Geral dos Contratos. 4a ed. São Paulo: Atlas, 2004. 
VIANA, Márcio Túlio. Fraude à Lei em Tempos de Crise. Revista do Tribunal Regional do Trabalho da 9a Região, v. 21, p. 61-70, jul./dez. 1996.

. Para entender a terceirização. São Paulo: LTr, 2017. 


\section{Anexos}

\section{Anexo A - PROJETO DE LEI Nº 8.174, DE 1986}

disposto no art. $53, \& 10^{\circ}$, da Constituição Federal, com-o restabelecimento do princípio isonômico.

oportuno destacar que o anteprojeto de lei procura evitar qualquer possibilidad de aumento imediato de despesa, sem reposicionamento automático, restrito à aplicacão do instituto da progressão funcional, nas épocas próprias.

Objetivando a manutençāo do princípio de igualdade de tratamento no âmbito do Poder Judiciario, introduziu-se; também, no anteprojeto de lei dispositivo permitindo que, na aplicação do disposto no art. 180 da Lei n.o 1.711, de 28 de outubro de 1952 , com a redação dada pela Lei n. ${ }^{\circ} 6.732$, de 4 de dezembro de 1979 , seja computado o tempo de servico do funcionario retribuido medinte Graticicaça de Representaça de da Lei n. $7.299 / 85$, tomada como paradigma.

A redação final do projeto de lei em causa observou fielmente as sugestöes da Secretaria de Planejamento da Presidência da República contidas no Parecer/GAT n. '53, de $10^{\circ}$ de novembro de 1985; no Parecer SOF/INOR n. 1.149 , de 3 de fevereiro de 1986, e no Ofício/SG n. ${ }^{\circ} 43$, de 13 dé fevereiro de 1986 e do Ministério da Administrafão, nos termos do Oficio n. 1.656 , de 16 de junho de 1986 , e do Ofício n. ${ }^{\circ} 1.673$, de 17 de junho de 1986 tendo ambas as referidas Pastas se manifestado favoráveis à iniciativa.

A medida encontra respaldo no art. 43, itens V e IX, e no art. 57, item IV, da

Com o, exposto, submeto à elevada apreciação de Vossa ibxcelência 0 anexo anteprojeto de lei, consubstanciando o restabeecimento da igualdade de tratamento que deve existir, sempre, entre os funcionário do Poder Judiciário.

Aproveito a oportunidade para renovar a Vossa Excelencia protestos de estima preço. - Paulo Brossard de Souza Pinto, Ministro da Justiça.

Proc. MJ n. ${ }^{\circ} 25.331 / 85$.

\section{PROJETO DE LEI}

N⿳亠े $^{\circ}$ 8.170, de 1986

(Do Senado Federal)

Dispóe sobre a emissão de selo come. morativo à Semana do Excepcional, de 21 a 28 de agosto, a cargo da Empresa Brasileira de Correios e Telégrafos ECT, e dá outras providências.

(Ass Comissóes de Constituição e Justiça, de Comunicação e Informática

o Congresso Nacional decreta:

Art. 1. ${ }^{\circ}$ a Empresa Brasileira de Correios e Telégrafos - ECT - autorizada a emitir selo comemorativo à Semana do Excepcional, de 21 a 28 de agosto; no valor de Cz\$ 5,00 (cinco cruzados) a unidade.

Art. 2.. O selo de que trata esta lei será facultativamente aposto nas cartas que tiverem de ser confiadas a Empresa Brasileir de Correios - ECT, independentemente do valor da tarifa respectiva, devendo o produto da arrecadação, com a sua venda, ser des-
Pestalozzi, para aplicação em favor das pessoas deficientes.

Art. 3..$^{\circ}$ Rsta lei entra em vigor na data de sua publicação.

Art. 4..$^{\circ}$ Revogam-se as disposiçôes em contrário.

Senado Federal, 21 de agosto de 1986. - Senador José Fragelli, Presidente. SINOPSE

PROJETO DE LEI DO SENADO N.a $75, \mathrm{DE} 1986$

Dispõe sobre a emissão de selo comemorativo à Semana do Excepeional, de 21 a 28 de agosto, a cargo da Empresa

ECT, e dá outras providências.

Apresentado pelo Senhor Senador Nelson Carneiro.

Lido no expediente da sessão de 25-3-86 e publicado no DCN (Seção II) de 26-3-86.

Distribuído às Comisōes de Constituição e Justica e de Economia.

Erm 15-8-86, é lido e aprovado, nesta data o Requerimento n. 376/86, subscrito pelo Senhor Senador Alfredo Campos e outros Líderes de urgência para a materia. Passando-se à sua apreciação são emitidos pelos Senhores Senadores Octávio Cardoso e Jorge Kálume, os pareceres, respectivamente, da CCJ e CEC, favoráveis, nos termos do substitutivo apresentado. Aprovado o substitutivo, em 1.0 turno, fica prejudicado o plor

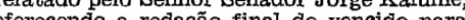
20 turno a no.

A Câmara dos Deputados com o Ofício SM-N.O 511, de 21-8-86.

\section{PROJETO DE LEI \\ № 8.174 , de 1986 \\ (Do Poder Executivo) MENSAGEM N N $^{4} 2 / 86$}

Disciplina o funcionamento das empresas de prestação de serviços a terceiros, altera a redação do $\$ 1^{\circ}$ do artigo $1^{\circ}$ da Lei no $^{\circ} .195$, de 19 de dezembro de 1974, que atribui ao FUNRURAL a concessão de prestaçōes por acidente do trabalho e do "caput" do arigo 36 da Lei $n^{p} 4.870$, de $1^{\circ}$ de dezent Instituto do Açúcar e do Ấlcool e sua aplicação, e dá outras providências.

(Ās Comissões de Constituição e Justiça, de Trabalho e de Economia, Indústria e Comércio).

O Congresso Nacional decreta:

Art. 19 São condições essenciais para que as empresas de prestação de serviços a terceiros possam funcionar no Território Nacional:

lar;

II - registro na Junta Comercial do Estado ou no Cartório de Registro de Pessoas Jurídicas da sua sede

III - capital integralizado mínimo de:

a) até 1.000 cmpregados - 1 (uma) vez o Maior Vade Referência - MVR, por empregado;

b) de 1.001 a 2.500 empregados - 4.000 (quatro mil) vezes o. Maior Valor de Referência - MVR

c) de 2.501 a 5.000 e,pregados -6.000 (seis mil) vees o Maior Valor de Referência - MVR.

d) mais de 5.000 empregados -8.000 (oito mil) vezes Maior Valor de Referência - MVR.

$\S 1^{\circ}$ A elevação do número de empregados importará em aumento de capital social, na forma prevista no inciso III deste artigo.
$\S 2^{q} \quad$ As empresas de prestação de serviços a terceiros já em funcionamento deverão proceder à sua adaptação aos preceitos deste artigo no prazo de 90 (noventa) dias,

a contar da data em que entrar $\mathrm{cm}$ vigor esta Lei. Art. $2^{\circ}$ As pessoas jurídicas de direito público ou privado e as pessoas fisicas tomadoras de serviços respondem solidariamente com a empresa contratada para prestaçào de serviços por todas as obrigações e encargos sociais decorrentes dos contratos de trabalho, assegurado o direito de ação regressiva.

Art. 3 Os salários pagos pela empresa de prestação de serviços a teceiros não poderão ser inferiores ao piso salarial estabclecido por acordo coletivo, convenção coetiva de trabalho ou por sentença normativa para a categoria profissiónal a que o trabalhador pertencer, respei-

$\S 1^{\circ}$ Na hipótese de inexistir piso salarial ou salário lário devido ñ̃o será inferior aosalário de serviço, o sagado que exercer as mesmas funções na empresa controtante due servicos ou em outra atividade similar na mesma praça ou localidade, garantido, em qualquer hipótese, o salário mínimo mensal.

$\$ 2^{2}$ Fica assegurado ao trabalhador de empresa de prestação de serviços a terceiros menor de 16 (dezesseis) anos de idade salário igual ao do trabalhador adulto, por unidade de tempo, de serviço ou de tarefa.

Art. 49 A empresa tomadora de serviços fica obrigada a apresentar, até o dia 10 do mês subsequlente ao do contratação, ao órgão local do Ministério do Trabalho, ou, na sua falta, ao Sindicato de Empregados, os motivos justificadores do trabalho e o número e a função do trabalhadores utilizados pela empresa contratada.

Art. 5 As empresas de prestação de serviços a terceiros deverão promover a qualificação profissional do trabalhadores quc executern tarefas nos serviços contra-

Parágrafo único. Para a qualificação profissional prevista neste artigo, as empresas de prestação de serviços a terceiros deverão comprovar que mantêm en lidade de profissional habilitado, segundo critérios determinados em regulamento.

Art. 6? Serão objeto de regulamentação: 1 - as obrigações das empresas tomadoras de serviço e das empresas de prestação de serviços a terceiros, referentes à segurança e medicina do trabalho, compreendido obrigatoriamente o serviço ambulatorial:

II - a utilização de restaurantes, refeitórios e vestiários da empresa tomadora de serviços pelos empregados da empresa de prestação de serviços a terceiros.

Art. $79 \quad \mathrm{O}$ contrato de prestação de serviços a terceiros, celebrado por escrito, conter obrigatoriamente: I -0 motivo justificador da necessidade de mão-deobra; tigo 15

III - a localidade de execução do contrato;

IV - a forma e valor de pagamento da empresa e dos trabalhadores contratado

V - a natureza dos trabalhos que serão executados; $\mathrm{VI}-\mathrm{a}$ modalidade de transporte, obrigatório em se tratando de rurais, a ser usado para o deslocamento dos trabalhadores.

Parágrafo único. A empresa de prestação de serviços tercciros devera elaborar uma folha de pagamento para cada contrato firmado, na forma do "caput" deste artigo, com discriminação do salário pago e os respectivos descontos.

Art. 8' O contrato individual de trabalho com empresa de prestação de serviços a terceiros, celebrado po escrito, deverá conter obrigatoriamente:

I - as características c condições específicas do trabaho;

II - a discriminação dos direitos conferidos por le aos trabalhadores.

Parágrafo único. Será nula de pleno direito qualque cláusula de reserva ou de exclusividade, visando proibi a contratação, pelo tomador de serviços ou pela empres de prestação de serviços a terceiros, do trabalhador, n vigência ou no final do prazo de duração do contrato. Art. 9: O contrato de trabalho será anotado na $\mathrm{Car}$ - 
Art. 10. O tomador de serviços deve comunicar, na forma da legislação previdenciária, à empresa de prestação de serviços a terceiros, a ocorrência de acidente o toenăo de do trabalho com relação ao trabalhador que esteja à sua disposição.

ja à sua disposição. ros, não poderá sob pena de devolução em triplo, cobra qualquer importância do trabalhador, sobretudo a título de mediação ou seguro, salvo os descontos previstos em

Art. 12. O salário do trabalhador de empresa de prestação de serviços a terceiros deverá ser pago median te comprovante hábil, que contenha:

I - nome do trabalhador;
II - firma ou razào social da empresa de prestação de

serviços a terceiros, e o respectivo endereço;

III - nome e endereço do tomador de serviço

IV - valores pagos e os descontos efetuados;

$\mathrm{V}$ - período da prestação de serviços a que se refere o pagamento.

Art. 13. Os serviços prestados, na forma prevista nesta lei, por empresas de prestação de serviços urbanos a terceiros, não poderão enquadrar-se no regime de trabalho temporário instituído pela Lei no 6.019 , de 3 de ja-
neiro de 1974 , nem corresponder à atividade fim da emneiro de 1974 , nem correspon
presa tomadora dos serviços.

presa tomadora dos serviços.
Art. 14. A mão-de-obra rural contratada com emArt. 14. A mão-de-obra rural contratada com $\mathrm{em}-$
presa de prestação de serviços rurais a terceiros só podepresa de prestaç utilizada:

rá ser utilizada:

produção agrícola, nos períodos normais da safra; II - no atendimento de necessidade transitória de substituição de pessoal permanente do tomador de ser-
viços, ou para execucũo de servicos extraordinários viços, ou para execução de serviços extraordinários inadiáveis, desde que devidamente justificada essa necessidade perante o órgão local do Ministério do Trabalho.
Art. 15. O contrato de prestação de serviços rurais Art. 15. O contrato de prestação de serviços rurais a
terceiros, relativo a um mesmo empregado, poderá te terceiros, relativo a um mesmo empregado, poderá te
prazo de duração de até 6 (seis) meses, prorrogável por prazo de duração de até 6 (seis) meses, prorrogável po gão local do Ministério do Trabalho.

Art. 16. O parágrafo $1^{\circ}$ do artigo $1^{\circ}$ da Lei número 6.195, de 19 de dezembro de 1974 , passa a vigorar com seguinte redação:

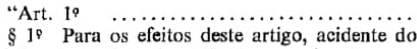
19 Para os efeitos deste artigo, acidente do
19alho é aquele assim definido no artigo $2^{\circ} \mathrm{e}$ seus trabalho é aquele assim definido no artigo $2^{\circ}$ e seus

Parágrafo único. Para custeio das despesas decorrentes da alteração de que trata o caput deste artigo, autoridade competente da Previdência Social fixará o acréscimo necessário à contribuição adicional prevista

Art. 17 O caput do artigo 36 , da Lei no 4.870 , de 1 de dezembro de 1965 , passa a vigorar com a seguinte redação:

“Art. 36. Ficam os produtores de cana, açúcar e álcool obrigados a aplicar, em benefício dos trabalhadores industriais, rurais e eventuais, contratados sob quaisquer formas e prazos, das usinas, destilarias e fornecedores, em serviços de assistência méd$\mathrm{ca}$, hospitalar, farmacêutica e social, inclusive aos
seus dependentes, importância correspondente, no seus dependentes, importância cor
mínimo, às seguintes percentagens:

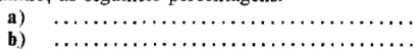

c)
$\S 1^{\circ}$
$\S 2^{\circ}$
$\S 3^{9}$

Art. 18. São depedentes dos trabalhadores referido no artigo 36 , da Lei $n^{\circ} 4.870$, de $1{ }^{\circ}$ de dezembro de 1965 , com a redação dada pelo artigo 17 desta Lei, as pessoa assim definidas nos termos e condições da Previdênci

Art. 19. Para efeito de participação nos serviços pre-
Social urbana. 1965 , co artigo 36, da Lei na 4.870 , de 10 de dezcros pro de 1965, com a redação dada pelo artigo 17 desta Lei, as usinas de açucar, destilarias de ácool o forisecedores de cana e, na falta deles, as chtidades sindicais de traballhadores rurais, fornecerão document
tho dos trabalhadores eventuais.
Art. 20. No que couber e no que não colidir com as disposições desta Lei, aplicam-se às relações de trabalho entre trabalhadores e suas empresas de prestação de serviços a terceiros a Consolidação das Leis do Trabalho e
legislaçào complementar, a Lei n de 1983, e a legislação trabalhista rural.

Art. 21. Competirá à Justiça do Trabalho dirimir os litígios entre as empresas de prestação de serviços a terceiros e seus trabalhadores.

Art. 22. Os infratores dos dispositivos desta Lei incorrerão na multa de 10 (dez) vezes o Maior Valor de Referência - MVR por empregado em atividade nos

serviços contratados.
$\S 1 \%$ No caso de reincidência, fraude, simulação e de resistência à fiscalização, a multa será aplicada em dobro e a empresa de prestação de serviços a terceiros ficará sujeita ao cancelamento do registro referido no inciso II do artigo 1? desta Lei.

$\S 2^{\circ}$ Tratando-se de entidade pública, as infrações serão comunicadas ao respectivo titular para apuração das responsabilidades e aplicação das sanções cabíveis. Art. 23. O processo de multas administrativas e os recursos obsc

do Trabalho.

Art. 24. O Poder Executivo regulamentará esta Lei no prazo de 120 (cento e vinte) dias a contar da data de sua publicaçào.

Art. 25. Esta Lei entra em vigor na data de sua

Art. 26. Revogam-se as disposições em contrário.
Brasilia, de 1986. LEGISLAÇÃO CITADA

LEI No 6.195

DE 19 DE DEZEMBRO DE 1974

Atribui ao FUNRURAL a concessão de prestações por cidente do trabalho.

O Presidente da República,

Faço saber que o Congresso Nacional decreta e en anciono a scguinte Lei:

Art. 19 O seguro de acidentes do trabalho rural de que trata o Artigo 19, da Lei n? 5.889, de junho de 1973, ricará a cargo do Fundo de Assistencia do Trabalhador

\& $1^{\circ}$ Para os efeitos deste artigo, acidente do trabatho é aquele assim definido no caput e no $\$ 22^{\circ}$ do

da Lei n 5.316 , de 14 de setembro de 1967.
$\& 29$ Equipara-se ao acidente do trabalho de que traeste artigo a doença profissional, inerente a atividade ural e definida em ato do Ministro da Previdência e Assistência Social.

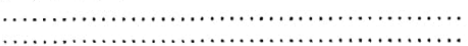
LEI N? 6.01

DE 3 DE JANEIRO DE 1974

Dispõe sobre o trabalho temporário nas empresas urbanas e dá outras providências.

O Presidente da República

Faço saber que o Congresso Nacional decreta e eu sanciono a seguinte Lei:

Art. 19 $\bar{E}$ instituído o regime de trabalho tempoário, nas condiçốcs estabelecidas na presente lei.

Art. $2^{9}$ Trabalho temporário é aqucle prestado por pssoa fisica a uma empresa, para atender à necessidade transitória de substituição de seu pessoal regular e pe

manente ou a acréscimo extraordinário de serviços.

Art. 3o É reconhecida a atividade da empresa de trabalho temporário que passa a integrar o plano básico do enquadramento sindical a que se refere o artigo 577 , d Consolidação das Leis do Trabalho.

Art. $4^{\circ}$ Compreende-se como empresa de trabalho temporário a pessoa física ou jurídica urbana, cuja atividade consiste em colocar à disposição de outras empresas, temporariamente, trabalhadores, devidamente quaficados, por elas remunerados $\mathrm{c}$ assistidos.

Art. $5^{\circ}$ O funcionamento da empresa de trabalho temporário dependerá de registro no Departamento $\mathrm{Na}$ cional de Mão-dc-Obra do Ministério do Trabalho e Previdência Social.

Art. $6^{\circ} \mathrm{O}$ pedido de registro para funcionar dever ser instruido com os seguintes documentos: a) prova de constituição da firma e de nacionalidade brasileira de seus sócios, com o competente registro na Junta Comercial da localidade em que tenha sede;

b) prova de possuir capital social de no mínimo quino País

c) prova de entrega da relação de trabalhadores a que se refere o artigo 360 , da Consolidação das Leis do Trabalho, bem como apresentação do Certificado de Regularidade de Situação, fornecido pelo Instituto Nacional de Previdência Social

d) prova do recolhimento da Contribuição Sindical; e) prova da propriedade do imóvel-sede ou recibo referente ao último mês, relativo ao contrato de locação; f) prova de inscrição no Cadastro Geral de ContriPes do Ministério da Fazenda.

Parágrafo único. No caso de mudança de sede ou de abertura de filiais, agências ou escritórios é dispensada a apresentaç̃̃o dos documentos de que trata este artigo, exigindo-sc, no entanto, o encaminhamento prévio ao Departamento Nacional de Mão-de-Obra de comunicação por escrito, com justificativa e endereço da nova sede ou das unidades operacionais da empresa.

Art. 79 A empresa de trabalho temporário que estiver flucionando na data da vigencia desta Lei terá o pra2o de noventa dias para o

Paragrafo unico. A empresa infratora do presente artigo poderá ter o seu funcionamento suspenso, por ato de-Obra cobendo recurso ao Ministro de Estado, no prazo , cabendo recurso ao Ministro de Estado, no Diário Oficial da União. Art. 8\& A empresa de trabalho temporário é obrigada a fornecer ao Departamento Nacional de Mão-de-

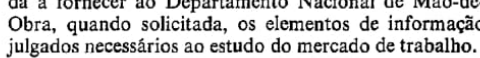

Art. 9: $\mathrm{O}$ contrato entre a empresa de trabalho temporário e a empresa tomadora de serviço ou cliente deve á ser obrigatoriamente escrito e dele deverá constar expressamente o motivo justificador da demanda de trabaração da prestação de serviço.

Art. 10. O contrato entre a empresa de trabalho emporário e a empresa tomadora ou cliente, com relaçâo a um mesmo empregado, não poderá exceder de do Miniterio do Trablho Previdencia Social scgundo to nstruções a serem b

Art. 11. O contrato de trabalho celebrado entre empresa de trabalho temporário e cada um dos assalariado colocados à disposiçáo de uma empresa tomadora ou cliente será, obrigatoriamente, escrito e dele devcrào constar, expressamente, os dircitos conferidos aos trabaPadores por esta Lei.

Parágrafo único. Será nula de pleno direito qualquer cláusula de reserva, proibindo a contratação do trabahador pela empresa tomadora ou cliente ao fim do prazo em que tenha sido colocado à sua disposição pela em-

Art. 12. Ficam assegurados ao trabalhador temporário os seguintes direitos:

a) remuneração equivalente à percebida pelos empregados de mesma categoria da empresa tomadora ou cliente calculados à base horária, garantida, em qual quer

b) je, a percepâa do salario minimo regional,

b) jornada de oito horas, remuneradas as horas ex$20 \%$ (vinte por cento);

Te artigo 25 da Lei n' 5.107, de 13 de setembro de 1966;

d) repouso semanal remunerado;

adicional por trabalho noturno

f) indenização por dispensa sem justa causa ou término normal do contrato, correspondente a $1 / 12$ (um doze av) do pagamento recebido

g) seguro contra acidente do trabalho;

h) proteção previdencíria nos termos do disposto n Lei Orgânica da Previdência Social, com as alteraçōes introduzidas pela Lei n' 5.890, de 8 de junho de 1973 (art tembro de 1973). 
Anexo B - PROJETO DE LEI No 4.302, DE 1998

PROJETO DE LEI No 4.302, DE 1998

(Do Poder Executivo)

Mensagem $\mathrm{n}^{\circ} 344 / 98$ Dispore sobre as relaçós de trabalho na empresa de trabalho
temporario e na empresa de prestaçà de serviços'a terceiros, e
da outras providéncias.

(AS COMISSOES DE TRABALHO, DE ADMINISTRAÇXO E SERVICCO POBLICO; E
DE CONSTITUIÇXO E JUSTIÇA $E$ DE REDAÇAO (ART. 54) - ART. 24, II)

O CONGRESSO NACIONAL decreta:

Art. $1^{\circ}$ As relaçōes de trabalho na empresa de trabalho temporário e na tomadora de seus servicos, e na empresa de prestaçăo de serviços a terceiros e na contratante de seus servicos
regem-se pelo disposto nesta Lei.

\section{DA EMPRESA DE TRABALHO TEMPORÁRIO}

Art. $2 *$ Compreendo-se como empress de trabalho temporirio a pessos juridica, de natureza comercial, cuja atividade consiste em colocar, temporariamente, trabalhadores por ela remunerados e assistidos a disposiçio de outra empresa, urbena ou rural.

Art. $3^{\circ}$ Compreende-se como empresa tomadora de serviço ou cliente a pessoa fisica ou juridica, urbana ou rural, que celebrar contrato com empresa de trabalho temporirio, objetivando docorrenze de greve, a demanda extraordinária de serviços ou a necessidade decorrente de variaçöes estacionais da atividade agríria.

Parigrafo único. Considera-se extraordináriz a demanda de serviços' oriunda de fatores imprevisiveis ou aquela derivada de fatores cuja ocorrencia, embora previsivel, seja intermitente ou periódica em escala anual.

Art. $4^{\circ}$ Compreende-se como trabalhador temporírio a pessos fisica contratada por empresa de trabalho temporivio para prestação de serviços em outra empresa, destinada a atender

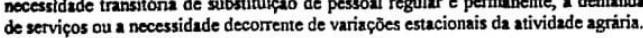

Art. 5 STo requisitos para o funcionamento das empresas de trabalho temporário:

I - prova de constituição da firma com o competente registro na Junta Comercial da unidade da federaçĩo em que tenha sede;

II - prova de possuir capital social igual ou superior so valor equivalente a 50.000 (cinquienta mil) Unidades Fiscais de Referència - UFIR;

III - prova de entrega da Relação Anual de Informaçð̌es Sociais - RAIS, bem como apresentacăo do Certificado de Regularidade junto ao Instituto Nacional do Seguro Social - INSS do Fundo de Garantia do Tempo de Serviço - FGTS;

IV - prova de recolhimento da contribuiçăo sindical:

V - prova de inscrição no Cadastro Geral de Contribuintes do Ministério da Fazenda.

Art. $6^{\circ} \mathrm{O}$ contrato firmado entre a empresa de trabalho temporário e a empres tomadora de serviço ou cliente será obrigatoriamente escrito, $e$ ficará à disposiçẵo da autoridade fiscalizadora na sede da empresa tomadora de serviço ou cliente, dele constando, expressamente, o motivo justificador da demanda de trabalho temporário $c$ as modalidades de remuneração da prestaçăo de serviço.

51- Durante a vigencia do contrato de trabalho, a empresa de trabalho temporário transfere $o$ poder diretivo sobre os seus trabalhadores à empresa tomadora de serviço ou cliente.

$\$ 2^{\circ} \mathrm{O}$ trabalhador temporário pode atuar tanto na atividade-meio quanto na atividade-fim da tomadora de serviço ou cliente.

Art. 70 o contrato entre a empresa de trabalho temporário e a tomadora de serviço ou cliente, com relacijo a um mesmo empregado, somente poderá exceder de seis meses, prorrogiveis por mais trís meses, quando atendido um dos seguintes pressupostos:

I - prestaç̧̧o de serviços destinada a atender necessidade transitória de substituiçāo de pessoal regular e permanente, nảo decorrente de greve, que exceder de seis meses;

II - manutenç̃o des circunstincias que geraram acréscimo extraordinário dos setvigos e ensecjeram a contratucilio de trabalbo temporírio.

Parigrafo único. A prorrogaçăo somente serh permitida queindo nino implicar na diminuicho dos postos de trabalho do quadro permanente de empregados da tomadora de serviço ou ctiente, considerando-se como bese a média do número de empregados permanentes nos últimos doses meses enterioces i promogacilo.

Art. 8. 0 contrato de trabalho celebrado entre a empresa de trabaltho temporário e

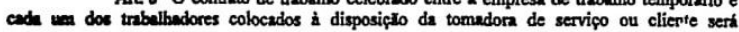

obrigatoriamente escrito, dele constarão expressamente os direitos conferidos aos trabalhadores por

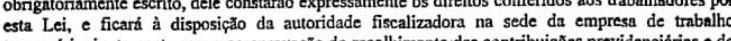
temporário, juntamente com a comprovaçãa do recollhimento das contribuiç̧̌s previdenciárias e do FGTS.

$\S 1^{\bullet} \mathrm{O}$ registro do trabalhador temporário limitar-se-á à anotaçẵo na Carteíra de $\S 1^{\circ}$ O registro do trabalhador temporánio limitar-se-á a anotaçăo na Carteira de
Trabalho e Previdência Social - CTPS de sua condiçắo de temporário e o periedo correspondente ao Trabalho e Previdéncia Socio
inicio e término do contrato.

$\S 2^{\circ} \mathrm{A}$ empresa de trabalho temporário é obrigada a elaborar folha de pagamento especial para os trabalhadores temporários.

$\$ 3^{\circ}$ É nula, não produzindo qualquer efeito, a cláusula de reserva que proiba a contratáçăo do trabalhador pela empresa tomadora de serviço oul cliente ao fim do prazo em que ele tenha sido colocado à sua disposiçăo pela empresa de trabal ho temporário.

$$
\text { Art. } 9 \text { São assegurados ao trabalhador temporário os seguintes direitos: }
$$

I - remuneraçăo equivalente ì percebida pelos' empregados de igual categoria da tomadora de serviço ou cliente, calculada com base na cargà horária, garantida em qualquer hipótese a percepçâo do salário minimo;

II - jornada de oito horas, salvo disposição legal em contrário, remuneradas as horas extraordinárias, não excedentes de duas, com acréscimo de no minimo $50 \%$ (cinqüenta por cento);

III - pagamento de férias proporcionais, no caso de dispensa sem justa causa ou érmino do prazo pre-fixado no contrato de trabalho, calculado na base de $1 / 12$ (um dore avos) cherior a 15 (quinze) dias, acrescido do $1 / 3$ (um terco) previsto no artigo $7^{\circ}$ inciso XVII o Constituiçăo Federal;

$$
\begin{aligned}
& \text { IV - décimo terceiro salário; } \\
& \text { V - repouso semanal remunerado; }
\end{aligned}
$$

VI - adicional por trabalho noturno, insalubre ou perigoso;

VII - recollimento para o Fundo de Garantia do Tempo de Servico - FGTS;

VIII - seguro contra acidente do trabelho;

IX - proteç̃o previdenciária nos termos da Lei Orgänica da Prescidência Social.

Parigrafo único. A tomadora de serviço ou cliente é obrigada a comunicar, nos termos da legislapão em vigor, ì empresa de traballho temporirio a ocorréncia de todo acidente cuja

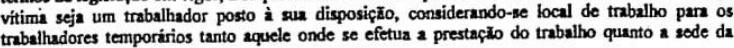
empresa de trabalho temporário.

Art. 10. Constituem justa causa para rescisão do contrato do trabalhador temporário os atos e circunstâncias enumerados nos artigos 482 e 483 da Consolidação das Leis do Trabalho CLT, que ocorram entre o trabalhador e a empresa de trabalho temporário ou entre ele e a tomador de serviço ou cliente onde estiver prestando o serviço.

Art. 11. A empresa de trabalho temporirio é obrigada a fornecer, mensalmente, tomadora de servico ou cliente comprovaşăo do pagamento dos salarios e da regularidade de sua tomadora de serviço ou cliente comprovasä̃o do pagamento dos salarios e da regularidade de sua situacăo com a

Art. 12. A tomadora de serviço ou cliente responde subsidiariamente pelas

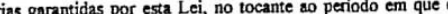
thathador estiver sob seu poder diretivo.

Art. 13. O Ministério do Trabalho fiscalizará o cumprimento das disposições desia Lei especialmente no tocante à manutençăo, no àmbito da empresa tomadora de serviço ou cliente. das condiç̄es previstas no seu art. $4^{\circ} \mathrm{e} \mathrm{no} \mathrm{paraggrafo} \mathrm{único} \mathrm{do} \mathrm{seu} \mathrm{art.} T^{\circ}$.

Paragrafo ünico. $O$ descumprimento do disposto no art. $4^{\circ}$ desta Lei enseja 0 encaminhamento de relatorio circunstaciado pela autoridade fiscalizadora no Ministério Público do Trabalho, conforme previsto na Lei Complementar n. ${ }^{\circ} 75$, de 20 de maio de 1993.

Art. 14. É vedado à empresa de trabalho temporário cobrar do trabalhador qualquer importàncis a título de intermediação de måo-de-obra, podendo apenas efeturr os descontos previstos em lei ou em convençăo ou acordo coletivo.

Art. 15. As alterą̧ões, durante a respectiva vigêncis, do contrato firmado entre a empresa de trabalho temporirio e a tomadora de seiviço ou cliente, que tenhsm por objeto a empresa de trabllo temporimero de trabalhadores colocados à sua disposiçio, serío formalizadas mediante termo aditivo, observado o disposto no artigo $6^{\circ}$ desta Lei.

Art. 16. É vedado à empresa de trabalho temporário ter ou utilizar em seus serviços trabalhador te utilizaçāo decorrer de contrato por ela firmado com oura empress de trabaltho temporáio.

Art. 17. As infrações ao disposto nesta Lei serão penalizadas com multa de 170 Unidades Fiscais de Referência - UFIR, por trabalhador prejudicado, dobrada no caeo de reincidéncia

Art. 18. Compete ì Justica do Trabalho dirimir os litigios ocorrentes entre as empresas de trabalho temporário.e seus trabalhadores. 


\section{DA EMPRESA DE PRESTACARÁ DE SERVTCOS A TERCEIROS}

Art. 19. Considern-se empress de prestaclo de servipos a vereciros a panou juridien de direito privadu, ' aealmente conssituida, que se destina a prestar determinado especifico servilio pera outra empresa, fora do imbito des atividades-fim e normais da comadora dos sexvicos.

$51^{\circ}$ As relaciós de trabaltho entre a empresa de prestapio de servipos a tercediros e seus empregados silo regidas pela CLT.

\$ $2^{\circ}$ A empresa de prestaclio de servicos a terceiros contran, romuneta e dirige o trabalho realizado por seus empregados.

83 $3^{\circ}$ Os empregados das empresas de prestaçio de servicos a terceiros năo se subordinam ao poder diretivo, técnico e disciplinar ḋa empresa contratante.

Art. 20. Considera-se contratante. para os efeitos desta Lei, a pesson fisica ou juridica, que celebrar contrato com empriwa d. .... taçăo de serviços a terceiros coma finalidede de

$\S 1^{\circ}$ Para a ceiebracão de contrato entre a empresa de presticialo de servicos terceiros $\mathrm{e}$ a con. atante, as atividades desenvolvidas por ambas, bem como suas finalidades, serio necessariamente distintas.

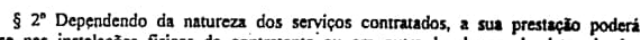
desenvolver-se nas instalaçōes fissicas da contratante ou em outro local por ela determinado, garantindo-se aos empregados as condiçōes de segurança e sáde no ambiente de trabaliho. previstas pela legislaçäo trabs

$\S 3^{\circ} \dot{E}$ vedado à contratante manter trabalhador em atividade diversa daquela para a qual ele foi contratado pela empress de prestação de servicos a terceiros.

Art. 21. A contratante è subsidiariamente responsivel pelas obrigacoes trabalhistas e previdenciärias garantidas por esta Lei, no tocante ao periodo em que ocorrer a prestafíto dos

\$1 1. Quando pertencentes ao mesmo grupo econômico, a empresu contratante ć solidariamente responsavel pelas obrigapess traballistas e previdenciarias relativas 20 par duraçảo do contrato, por ela firmado com a empresa de prestaçio de servicos a tercetiros.

\$f $2^{\circ}$ A empresa de prestaçăo de servicos a terceiros é obrigada a fornecer, mensalmente, i contratante comprovacia do pagamento dos salirios e da regularidade de sua situsçăo com a Previdència Social e o FGTS, bem como cópia des respectivas guins de. recolhimento.

Art. 22. Presentes os elementos constitutivos da relaçio de emprego previstos na CLT, configurar-se-i o vinculo empregaticio entre a empress contratante e os trabalhadores colocados ì sua disposiçio pela empresa de prestaçio de serviços a terceiros, o mesmo ocorrendo quando a trabalho por eles prestado caracterizar desvio de funçio.

Capitulo III

DISPOSICǑES GERAIS

Art. 23. A empresa de trabalho temporirio e a de prestaço de servicos a terceiros Art. 23. A empresa de trabalho temporário ea de prestaça de servicos 2 terceiros
poderăo adotar como objeto social, simultaneamente, o fornecimento de trabalho temporirio e a poderão adotar como objeto sociall
prestaçăo de serviços a terceiros.

Parágrafo único. Caso opte pelo objeto social referido no caput deste artigo, empresa de trabalho temporirio e a de prestaçäo de serviços a terceiros elaborario a folha de pagamento especial prevista no $\S 2^{\circ}$ do art. $8^{\circ}$ desta Lei.

Art. 24. As empresas de trabalho temporário $e$ as de prestupio de servicos a terceiros em funcionamento na datz da vigència desta Lei teräo o prazo de noventa dias, a contar de sua pubblicaçăo, para se adequar às exigências nela contidas.

Art. 25. O disposto nesta Lei não se aplica às empresas de vigilinncia e de transpone de valores, pern!anecentio as respectivas relaçōes de trabalho reguladas por legislaçio especial, subsidiarianien:e pela CLT.

de janeiro de 1974

Art. 26. Esta Loi entra em vigor na data de sua publicaçăo.

Art. 27. Revoguam-se as disposiçōes em contrário, especialmente a Lei n.: 6.019, de 3

"LEGISLACX̃o CTTADA ANEXADA PELA

COORDENAÇÃO DE ESTUUDOS LEGISLATTVOS-CEDr'

\section{CONSTITUIÇÃO}

DA

REPÚBLICA FEDERATIVA DO BRASIL 1988

TITULO II

Dos Direitos e Garantias Fundamentais
CAPÍTULO II

Dos Direitos Sociais

Art. $7 \Upsilon^{-}$S\$o direitos dos trabalhadores urbanos e rurais, além de outros que visem à melhoria de sua condição social:

XVII - gozo de férias anuais remuneradas com, pelo menos, um terço a mais do que o salário normal;

TÍTULO IV
Da Organização dos Poderes
CAPÍTULO I
Do Poder Legislativo
DEÇÃO VIII Processo Legislativo
SUBSEÇÃo III
Das Leis

Art. 61 - A iniciativa das leis complementares e ordinárias cabe a qualquer membro ou Comissã̀o da Câmara dos Deputados, do Senado Federal ou do Congresso Nacional, ao Presidente da República, ao Supremo Tribunal Federal, aos Tribunais Superiores, ao Procurador-Geral da República e aos cidadãos, na forma e nos casos previstos nesta Constituição.

$\S 1^{\circ}$ - São de iniciativa privativa do Presidente da República as leis que:

I - fixem ou modifiquem os efetivos das Forças Armadas;

II - disponham sobre:

a) criação dè cargos, funções ou empregos públicos na administração direta e autárquica ou aumento de sua remuneração;

b) organização administrativa e judiciária, matéria tributária orçamentária, serviços públicos e pessoal da administração dos Territórios;

c) servidores públicos da União e Territórios, seu regime jurídico, provimento de cargos, estabilidade $\mathrm{e}$ aposentadoria de civis, reforma $\mathrm{e}$ transferência de militares para a inatividade;

d) organização do Ministério Público e da Defensoria Pública da União, bem como normas gerais para a organização do Ministérịo Público e da Defensoria Pública dos Estados, do Distrito Federal e dos Territórios;

e) criação, estruturação e atrịbuições dos Ministérios e. órgãos da administração pública.

\& $2^{\circ}$ - A iniciativa popular pode ser exercida pela apresentação à Câmara dos Deputados de projeto de leí subscrito por, no mínimo, um por cento do eleitorado nacional, distribuído pelo menos por cinco Estados, com não menos de três décimos por cento dos eleitorẹ de cada um deles.

\section{LEI COMPLEMENTAR No 75, DE 20 DE MAIO DE 1993}

DISPŐE SOBRE A ORGANIZAÇ̃̃O, AS ATRIBUIÇÕES E O ESTATUTO DO MINISTÉRIO PÚBLICO DA UNIÃO. 
Anexo C - PROJETO DE LEI No 4.330, DE 2004

PROJETO DE LEI №

, DE 2004

(Do Sr. Sandro Mabel)

\author{
Dispõe sobre o contrato de prestação \\ de serviço a terceiros e as relações de \\ trabalho dele decorrentes.
}

O Congresso Nacional decreta:

Art. 1ํ Esta Lei regula o contrato de prestação de serviço e as relações de trabalho dele decorrentes, quando o prestador for sociedade empresária que contrate empregados ou subcontrate outra empresa para a execução do serviço.

Parágrafo único. Aplica-se subsidiariamente ao contrato de que trata esta Lei o disposto no Código Civil, em especial os arts. 421 a 480 e 593 a 609 .

Art. $2^{\circ}$ Empresa prestadora de serviços a terceiros é a sociedade empresária destinada a prestar à contratante serviços determinados e específicos.

$\S 1^{\circ} \mathrm{A}$ empresa prestadora de serviços contrata e remunera o trabalho realizado por seus empregados, ou subcontrata outra empresa para realização desses serviços.

$\S 2^{\circ}$ Não se configura vínculo empregatício entre a empresa contratante e os trabalhadores ou sócios das empresas prestadoras de serviços, qualquer que seja o seu ramo. 
Art. $3^{\circ}$ São requisitos para o funcionamento da empresa de prestação de serviços a terceiros:

Jurídica (CNPJ);

I - prova de inscrição no Cadastro Nacional de Pessoa

II - registro na Junta Comercial;

III - capital social compatível com o número de empregados, observando-se os seguintes parâmetros:

a) empresas com até dez empregados: capital mínimo de $\mathrm{R} \$ 10.000,00$ (dez mil reais);

b) empresas com mais de dez e até vinte empregados: capital mínimo de $R \$ 25.000,00$ (vinte e cinco mil reais);

c) empresas com mais de vinte e até cinqüenta empregados: capital mínimo de $\mathrm{R} \$ 45.000,00$ (quarenta e cinco mil reais);

d) empresas com mais de cinqüenta e até cem empregados: capital mínimo de $R \$ 100.000,00$ (cem mil reais); e

e) empresas com mais de cem empregados: capital mínimo de $R \$ 250.000,00$ (duzentos e cinqüenta mil reais).

$\S 1^{\circ}$ Convenção ou acordo coletivo de trabalho podem exigir a imobilização do capital social em até cinqüenta por cento dos valores previstos no inciso III deste artigo.

$\S 2^{\circ}$ O valor do capital social de que trata o inciso III deste artigo será reajustado:

I - no mês de publicação desta lei, pela variação acumulada do Índice Nacional de Preços ao Consumidor (INPC), da Fundação Instituto Brasileiro de Geografia e Estatística (IBGE), verificada de novembro de 2004, inclusive, ao mês imediatamente anterior ao do início de vigência desta lei;

II - anualmente, a partir do ano subseqüente ao do reajuste mencionado no inciso anterior, no mês correspondente ao da publicação desta lei, pela variação acumulada do INPC nos doze meses imediatamente anteriores. 
Art. $4^{\circ}$ Contratante é a pessoa física ou jurídica que celebra contrato de prestação de serviços determinados e específicos com empresa prestadora de serviços a terceiros.

$\S 1^{0}$ É vedada à contratante a utilização dos trabalhadores em atividades distintas daquelas que foram objeto do contrato com a empresa prestadora de serviços.

$\S 2^{\circ} \mathrm{O}$ contrato de prestação de serviços pode versar sobre o desenvolvimento de atividades inerentes, acessórias ou complementares à atividade econômica da contratante.

Art. $5^{\circ}$ São permitidas sucessivas contratações do trabalhador por diferentes empresas prestadoras de serviços a terceiros, que prestem serviços à mesma contratante de forma consecutiva.

Art. 6ㅇ Os serviços contratados podem ser executados no estabelecimento da empresa contratante ou em outro local, de comum acordo entre as partes.

Art. $7^{\circ}$ É responsabilidade da contratante garantir as condições de segurança e saúde dos trabalhadores, enquanto estes estiverem a seu serviço e em suas dependências, ou em local por ela designado.

Art. 8ำ Quando o empregado for encarregado de serviço para o qual seja necessário treinamento específico, a contratante deverá:

I - exigir da empresa prestadora de serviços a terceiros certificado de capacitação do trabalhador para a execução do serviço; ou

II - fornecer o treinamento adequado, somente após o qual poderá ser o trabalhador colocado em serviço.

Art. 9o A contratante pode estender ao trabalhador da empresa de prestação de serviços a terceiros benefícios oferecidos aos seus empregados, tais como atendimento médico, ambulatorial e de refeição destinado aos seus empregados, existentes nas dependências da contratante ou local por ela designado.

Art. 10. A empresa contratante é subsidiariamente responsável pelas obrigações trabalhistas referentes ao período em que ocorrer a prestação de serviços, ficando-Ihe ressalvada ação regressiva contra a devedora. 
Parágrafo único. Na ação regressiva de que trata o caput, além do ressarcimento do valor pago ao trabalhador e das despesas processuais, acrescidos de juros e correção monetária, é devida indenização em valor equivalente à importância paga ao trabalhador.

Art. 11. A empresa prestadora de serviços a terceiros, que subcontratar outra empresa para a execução do serviço, é solidariamente responsável pelas obrigações trabalhistas assumidas pela empresa subcontratada.

Art. 12. Nos contratos de prestação de serviços a terceiros em que a contratante for a Administração Pública, a responsabilidade pelos encargos trabalhistas é regulada pelo art. 71 da Lei no 8.666 , de 21 de junho de 1993.

Art. 13. O recolhimento das contribuições previdenciárias relativas aos trabalhadores contratados para a prestação de serviços a terceiros observa o disposto no art. 31 da Lei no 8.212, de 24 de julho de 1991.

Art. 14. O contrato de prestação de serviços a terceiros deve conter, além das cláusulas inerentes a qualquer contrato:

I - a especificação do serviço a ser prestado;

II - o prazo para realização do serviço, quando for o caso;

III - a obrigatoriedade de apresentação periódica, pela empresa prestadora de serviços a terceiros, dos comprovantes de cumprimento das obrigações trabalhistas pelas quais a contratante é subsidiariamente responsável.

Art. 15. O recolhimento da contribuição sindical prevista nos arts. 578 e seguintes da Consolidação das Leis do Trabalho (CLT) deve ser feito ao sindicato representante da categoria profissional correspondente à atividade exercida pelo trabalhador na empresa contratante.

§ 1 A contribuição sindical devida pelo trabalhador de empresa de prestação de serviços a terceiros, contratado para o cumprimento do contrato de que trata esta Lei, é proporcional ao período em que foi colocado à disposição da empresa contratante e consiste na importância correspondente a um doze avos da remuneração de um dia de trabalho por mês de serviço ou fração superior a quatorze dias. 
$\S 2^{\circ}$ Não é devida a contribuição pelo trabalhador se este já houver pago, no mesmo ano, a título de contribuição sindical, importância correspondente à remuneração de um dia de trabalho, nos termos do art. 582 da CLT.

Art. 16. O disposto nesta Lei não se aplica:

1 - à prestação de serviços de natureza doméstica, assim entendida aquela fornecida à pessoa física ou à família no âmbito residencial destas;

II - às empresas de vigilância e transporte de valores, permanecendo as respectivas relações de trabalho reguladas por legislação especial.

Art. 17. O descumprimento do disposto nesta Lei sujeita a empresa infratora ao pagamento de multa administrativa de $R \$ 500,00$ (quinhentos reais) por trabalhador prejudicado, salvo se já houver previsão legal de multa específica para a infração verificada.

$\S 1^{\circ}$ A fiscalização, a autuação e o processo de imposição de multas reger-se-ão pelo Título VII da CLT.

$\S 2^{0}$ As partes ficam anistiadas das penalidades não compatíveis com esta Lei, impostas com base na legislação anterior.

Art. 18. Os contratos em vigência serão adequados aos termos desta Lei no prazo de cento e vinte dias a partir da vigência.

Art. 19. Esta Lei entra em vigor trinta dias após a publicação.

\section{JUSTIFICAÇÃO}

O mundo assistiu, nos últimos 20 anos, a uma verdadeira revolução na organização da produção. Como conseqüência, observamos também profundas reformulações na organização do trabalho. Novas formas de contratação foram adotadas para atender à nova empresa. 
Nesse contexto, a terceirização é uma das técnicas de administração do trabalho que têm maior crescimento, tendo em vista a necessidade que a empresa moderna tem de concentrar-se em seu negócio principal e na melhoria da qualidade do produto ou da prestação de serviço.

No Brasil, a legislação foi verdadeiramente atropelada pela realidade. Ao tentar, de maneira míope, proteger os trabalhadores simplesmente ignorando a terceirização, conseguiu apenas deixar mais vulneráveis os brasileiros que trabalham sob essa modalidade de contratação.

As relações de trabalho na prestação de serviços a terceiros reclamam urgente intervenção legislativa, no sentido de definir as responsabilidades do tomador e do prestador de serviços e, assim, garantir os direitos dos trabalhadores.

A presente proposição tem origem no Projeto de Lei no 4.302, de 1998, que após mais de cinco anos de tramitação, teve a retirada solicitada pelo Poder Executivo. Ressalta-se que durante a tramitação do Projeto de Lei do Executivo, que também alterava a lei do trabalho temporário, travaramse longos e frutíferos debates sobre o tema, tanto nesta Casa quanto no Senado Federal, que muito enriqueceram a proposta original.

O Projeto de Lei que ora apresentamos exclui os dispositivos que tratavam do trabalho temporário, limitando-se à prestação de serviços a terceiros, e incorpora as contribuições oferecidas por todos os que participaram dos debates do Projeto de Lei № 4.302, de 1998.

A nossa proposição regula o contrato de prestação de serviço e as relações de trabalho dele decorrentes. O prestador de serviços que se submete à norma é, portanto, a sociedade empresária, conforme a nomenclatura do novo Código Civil, que contrata empregados ou subcontrata outra empresa para a prestação de serviços.

Deve ser destacada a definição da empresa prestadora de serviços como aquela que presta serviços determinados e específicos para a empresa contratante. É a prestadora responsável pela contratação, remuneração e direção do trabalho de seus empregados, podendo, ainda, subcontratar outras empresas para realizar os serviços contratados.

Não há, obviamente, vínculo empregatício entre a tomadora de serviços e os trabalhadores contratados pela prestadora ou seus sócios. 
São estabelecidos requisitos para o funcionamento das empresas prestadoras de serviço que visam a garantir o adimplemento das obrigações trabalhistas e previdenciárias. O capital social mínimo estipulado em função do número de empregados é um exemplo.

É prevista, ainda, a possibilidade de ser exigida a imobilização de até $50 \%$ do capital social da prestadora de serviços mediante acordo ou convenção coletiva de trabalho.

A nossa proposição define também a figura do contratante que pode ser pessoa física ou jurídica. A inclusão de pessoa física justifica-se pela necessidade de permitir a contratação de prestadoras de serviço por profissionais liberais.

Vários dispositivos estipulam limitações contratuais que protegem o trabalhador, como a vedação de sua utilização, pela empresa contratante, em atividades diversas das estipuladas em contrato com a empresa prestadora de serviços.

O objeto da contratação deve ser especificado. É, no entanto, amplo, podendo versar sobre atividades inerentes, acessórias ou complementares à atividade econômica da contratante.

Uma das situações que muito nos preocupou foi a possibilidade de um trabalhador continuar prestando serviços a uma empresa contratante, ainda que se sucedam várias empresas prestadoras de serviço. Optamos por abordar o tema no art. $5^{\circ}$, permitindo a continuidade do trabalho para a mesma empresa contratante.

A empresa contratante é diretamente responsável pelas condições de segurança e saúde do ambiente de trabalho.

Além disso, caso seja necessário treinamento específico para a realização do trabalho, a empresa contratante pode exigir da prestadora o certificado de capacitação do trabalhador ou pode fornecer 0 treinamento adequado.

Uma das maiores críticas que se faz à terceirização é a precarização das relações de trabalho dela decorrentes, apresentando altos índices de acidentes do trabalho. Atribuir a responsabilidade à contratante por 
esse aspecto ligado às condições de trabalho representa uma garantia ao trabalhador e, certamente, contribui para a melhoria do ambiente laboral.

É prevista a responsabilidade subsidiária da contratante quanto às obrigações trabalhistas, sendo-lhe assegurado, obviamente, o direito de ação regressiva contra a prestadora de serviços / devedora.

O projeto inova ao assegurar mediante a ação regressiva, além do ressarcimento dos valores pagos pela contratante, o pagamento de uma indenização equivalente ao valor pago ao trabalhador.

Há, ainda, previsão de responsabilidade solidária quanto às obrigações trabalhistas pela empresa prestadora de serviços que subcontratar outra empresa.

No caso de contratação com a Administração Pública, o projeto remete à Lei no 8.666, de 21 de junho de 1993, que "regulamenta 0 artigo 37, inciso XXI, da Constituição Federal, institui normas para licitações e contratos da Administração Pública e dá outras providências".

Isso significa que a Administração Pública é solidariamente responsável quanto aos encargos previdenciários, mas não quanto às dívidas trabalhistas.

O contrato de prestação de serviços deve conter a especificação do serviço a ser prestado e o prazo para a sua realização. Deve, além disso, prever a apresentação periódica, pela empresa prestadora de serviços, dos comprovantes de cumprimento das obrigações trabalhistas, o que possibilitará a fiscalização por parte da empresa contratante.

Outro aspecto relevante da proposição é que o recolhimento da contribuição sindical compulsória deve ser feito à entidade representante da categoria profissional correspondente à atividade terceirizada. Aumenta-se, dessa forma, o poder de negociação com as entidades patronais, bem como é favorecida a fiscalização quanto à utilização correta da prestação de serviços.

São excluídas da aplicação da lei as atividades de empregado doméstico, e ainda as atividades de vigilância e transporte de valores, que já possuem legislação específica. 
É estabelecida multa administrativa de $\mathrm{R} \$ 500,00$ (quinhentos reais) por trabalhador prejudicado em caso de descumprimento da norma.

É concedida anistia aos débitos, penalidades e multas impostas com base em normas não compatíveis com a lei.

A proposição concede prazo de cento e vinte dias para a adequação dos contratos vigentes aos termos da nova lei, sendo que a vigência ocorrerá trinta dias após a publicação.

Tal prazo, acreditamos, é suficiente para que as partes interessadas tenham ciência das alterações e adeqüem seus contratos.

Destacamos, ainda, que a proposição é fruto de discussão com vários segmentos da sociedade. Tal discussão não está encerrada. Deve, outrossim, ser ampliada, a fim de aprimorar o texto da norma. Colocamo-nos, desde já, à disposição daqueles que queiram contribuir para a regulação dessa matéria, tão relevante para as relações de trabalho no Brasil.

Por considerarmos de alta relevância a regulamentação da terceirização, rogamos aos nobres Colegas pela aprovação deste Projeto de Lei.

Sala das Sessões, em de de 2004.

Deputado Sandro Mabel

2004.12234.999 


\title{
Anexo D - PROJETO DE LEI Nº 5.439, DE 2005
}

\section{PROJETO DE LEI № ， DE 2005 \\ (Da Sra. ANN PONTES )}

\author{
Acrescenta dispositivo \\ à \\ Consolidação das Leis do Trabalho - CLT, \\ proibindo a contratação de mão de obra por \\ empresa interposta.
}

O Congresso Nacional decreta:

Art. 1 Art. 10 A Consolidação das Leis do Trabalho CLT, aprovada pelo Decreto-lei $n^{\circ} 5.452$, de $1^{\circ}$ de maio de 1943, passa a vigorar acrescida do seguinte art. 442-A:

"Art. 442-A Salvo nos casos de trabalho temporário, serviços de vigilância, conservação e limpeza, é vedada a contratação de trabalhador por empresa interposta, formando-se o vínculo empregatício diretamente com o tomador dos serviços.

Parágrafo único. $O$ inadimplemento das obrigações trabalhistas, previdenciárias e tributárias por parte do empregador, implica a responsabilidade solidária do tomador de serviços quanto àquelas obrigações, desde que este tenha participado da relação processual e conste do título executivo judicial."

Art. $2^{\circ}$ Esta lei entra em vigor na data de sua publicação. 


\section{JUSTIFICAÇÃO}

Com o presente projeto, estamos propondo transformar verbete da jurisprudência dominante do Tribunal Superior do Trabalho sobre a matéria em norma jurídica.

Enunciado ํo 331 do Tribunal Superior do Trabalho - TST

assim dispõe:

"I - A contratação de trabalhadores por empresa interposta é ilegal, formando-se o vínculo diretamente com o tomador de serviços, salvo no caso de trabalho temporário (Lei no 6.019, de 3-1-74).

II - A contratação irregular de trabalhador, através de empresa interposta, não gera vínculo de emprego com os órgãos da Administração Pública Direta, Indireta ou Fundacional (art. 37, II, da Constituição da República).

III - Não forma vínculo de emprego com o tomador a contratação de serviços de vigilância (Lei no 7.102 , de 20-6-83), de conservação e limpeza, bem como a de serviços especializados ligados à atividade-meio do tomador, desde que inexistente a pessoalidade e a subordinação.

IV - O inadimplemento das obrigações trabalhistas, por parte do empregador, implica na responsabilidade subsidiária do tomador dos serviços quanto àquelas obrigações, desde que este tenha participado da relação processual e conste também do título executivo judicial."

Assim, a orientação da mais alta corte trabalhista restringe a hipótese de contratação por empresa interposta e conclui pela responsabilidade subsidiária do tomador de serviços, garantindo o pagamento ao trabalhador das verbas decorrentes da relação de emprego. 
No entanto, o verbete de jurisprudência não obriga os tribunais regionais, nem as varas de trabalho, a ter a mesma posição, que pode divergir, gerando entendimentos diversos e adiando o recebimento das verbas devidas ao trabalhador que processa a empresa, em virtude da amplitude de recursos cabíveis.

Assim, a proposta representa avanço na proteção dos diretos trabalhistas, se atendo aos aspectos principais da jurisprudência firmada pelo TST.

Representa, outrossim, maior proteção do trabalhador ao estabelecer a responsabilidade solidária do tomador de serviços. Isso significa que o empregado pode processar tanto a empresa tomadora de serviços, quanto a empresa que presta serviços a terceiros.

No modelo em vigência, apenas se a empresa prestadora de serviços for inadimplente e não realizar os pagamentos julgados procedentes na Justiça, a tomadora é chamada a pagar as verbas trabalhistas.

Nos termos do projeto, com a responsabilidade solidária, qualquer uma das empresas pode ser processada, devendo, para efeito de condenação, participar da relação processual (pois o processo não pode atingir terceiros) e constar do título executivo judicial.

Entendemos que a proposição pode efetivamente contribuir para a melhoria das relações trabalhistas, evitando que ocorram fraudes à legislação e a precarização, mediante a terceirização, dessas relações.

É para por fim a essa prática, condenada pela OIT e por todos os países civilizados, sendo inclusive imputada como crime em alguns deles, que contamos com o apoio dos nobres colegas na aprovação deste projeto.

Sala das Sessões, em de de 2005. 


\section{Anexo E - PROJETO DE LEI No 1.621, DE 2007}

\section{PROJETO DE LEI Nº , DE 2007}

(Do Senhor Vicentinho)

Dispõe sobre as relações de trabalho em atos de terceirização e na prestação de serviços a terceiros no setor privado e nas sociedades de economia mista.

\section{O CONGRESSO NACIONAL decreta:}

Art. $1^{\circ}$. A presente Lei dispõe sobre as relações de trabalho em atos de terceirização e na prestação de serviços a terceiros no setor privado e nas sociedades de economia mista.

Art. $2^{\circ}$. Para fins de aplicação desta lei, consideram-se os seguintes conceitos de terceirização, tomadora e prestadora de serviços:

I - terceirização é a transferência da execução de serviços de uma pessoa jurídica de direito privado ou sociedade de economia mista para outra pessoa jurídica de direito privado;

II - tomadora é a pessoa jurídica de direito privado ou sociedade de economia mista que contrata serviços de outra pessoa jurídica prestadora;

III - prestadora é a pessoa jurídica de direito privado que exerce atividade especializada e que, assumindo o risco da atividade econômica, contrata, assalaria e comanda a prestação de serviços para uma tomadora.

Art. $3^{\circ}$. É proibida a terceirização da atividade-fim da empresa.

$\S 1^{\circ}$ - Entende-se por atividade fim, o conjunto de operações, diretas e indiretas que guardam estreita relação com a finalidade central em torno da qual a empresa foi constituída, está estruturada e se organiza em termos de processo de trabalho e núcleo de negócios. 
$\S 2^{\circ}$ - Na atividade fim da empresa não será permitida a contratação de pessoa jurídica, devendo tais atividades serem realizadas somente por trabalhadores diretamente contratados com vínculo de emprego.

Art. $4^{\circ} \mathrm{A}$ empresa que pretenda terceirizar serviços informará ao sindicato respectivo da sua categoria profissional, com no mínimo seis meses de antecedência, sobre os projetos de terceirização.

$\S$ único. No ato de comunicação dos projetos, a empresa deverá fornecer ao sindicato da categoria profissional, dentre outras, as seguintes informações:

I - os motivos da terceirização;

II - os serviços que pretende terceirizar;

III - o número de trabalhadores diretos e indiretos envolvidos na terceirização;

IV - a redução de custos pretendida;

V - os locais de prestação dos serviços;

$\mathrm{VI}$ - que prestadoras pretende contratar para executar os serviços, exceto empresas de economia mista, por terem regulamentação própria.

Art. $5^{\circ}$ No contrato de prestação de serviços firmado entre a tomadora e a prestadora deverá constar a especificação dos serviços a serem executados e seu prazo de duração.

Art. $6^{\circ} \mathrm{A}$ tomadora deverá exigir da prestadora e manter sob sua guarda, para fins de controle e fiscalização, cópia dos seguintes documentos:

a) comprovação do Registro da prestadora na Junta Comercial;

b) comprovação do capital social integralizado da prestadora, suficiente para garantir a satisfação dos direitos e créditos trabalhistas, inclusive na rescisão;

c) comprovação de entrega da Relação Anual de Informações Sociais (RAIS) pela prestadora;

d) Certidão Negativa de Débito Previdenciário (CND) pela prestadora;

e) comprovação da propriedade do imóvel-sede ou recibo referente ao último mês, relativo ao contrato de locação da prestadora;

f) inscrição da prestadora no Cadastro Nacional de Pessoas Jurídicas (CNPJ) da Secretaria da Receita Federal; 
g) comprovação pela prestadora de regularidade do Fundo de Garantia por Tempo de Serviço (FGTS) expedida pela Caixa Econômica Federal;

h) certidão negativa de infrações trabalhistas pela prestadora, expedida pelos órgãos locais do Ministério do Trabalho e Emprego:

i) acordo coletivo ou convenção coletiva.

Parágrafo Único: Os itens $d, g$ e $h$ deverão ser entregues mensalmente pela prestadora.

Art. $7^{\circ}$ - Dependendo da natureza dos serviços contratados, a sua prestação poderá desenvolver-se nas instalações físicas da tomadora ou em outro local, respeitadas, em quaisquer das hipóteses, as seguintes exigências:

I - não haverá distinção de salário, jornada, benefícios, ritmo de trabalho e condições de saúde e de segurança entre os empregados da tomadora e os empregados da prestadora que atuem nas instalações físicas da tomadora ou em outro local por ela determinado:

II - a tomadora será responsável em garantir aos empregados da prestadora, enquanto estes estiverem a seu serviço, os gastos com o deslocamento, bem como, com as acomodações destinadas ao trabalhador terceirizado deslocado do lugar onde iniciou a prestação do serviço;

III - é vedado à tomadora manter empregado em atividade diversa daquela para a qual foi contratado pela prestadora;

IV - os empregados da prestadora não poderão ser subordinados ao comando disciplinar e diretivo da tomadora;

V - a tomadora não poderá exigir a pessoalidade na prestação de serviços.

Art. $8^{\circ}$ É proibida a contratação de prestadoras constituídas com a finalidade de fornecer mão-de-obra, ressalvados os casos de trabalho temporário, serviços de vigilância e asseio e conservação.

Art. $9^{\circ}$ - A tomadora é solidariamente responsável, independentemente de culpa, pelas obrigações trabalhistas, previdenciárias e quaisquer outras decorrentes do contrato de prestação de serviços, inclusive nos casos de falência da prestadora.

$\S 1^{\circ}$. A prestadora é obrigada a fornecer, mensalmente, à tomadora comprovação do pagamento dos salários, do recolhimento das contribuições previdenciárias e do FGTS, bem como cópia das respectivas guias de recolhimento, devendo tais informações e documentos serem fornecidos pela prestadora ou tomadora aos sindicatos das categorias profissionais sempre que por eles solicitados. 
$\S 2^{\circ}$. A tomadora assegurará o pagamento imediato de salários, $13^{\circ}$ salário, férias com o terço constitucional e recolhimento de FGTS, sempre que a prestadora deixar de cumprir estas obrigações com seus trabalhadores.

Art. 10. Haverá vínculo empregatício entre a tomadora e os empregados da prestadora, sempre que presentes os elementos previstos no artigo $3^{\circ}$ da Consolidação das Leis do Trabalho, que caracterizam a relação de emprego - ressalvados os casos que exigem concurso público para a sua admissão, sem prejuízo do previsto no caput e $\S 1^{\circ}$ do artigo $9^{\circ}$.

Art. 11. Será assegurado aos sindicatos das categorias profissionais representarem os empregados administrativa e judicialmente, na qualidade de substituto processual, com o objetivo de assegurar o cumprimento do disposto nesta Lei.

Art. 12. Será constituída Comissão formada por representantes das empresas prestadoras, contratadas e sindicatos de trabalhadores para acompanhamento dos contratos de prestação de serviços.

Art. 13. O descumprimento do disposto nesta Lei sujeita os infratores (tomador e prestador) ao pagamento de multa percentual de $10 \%$ (dez por cento) sobre o valor do contrato de terceirização em favor do trabalhador prejudicado, se movida por este Reclamação Trabalhista perante a Justiça do Trabalho.

$\S 1^{\circ}$. No caso de reincidência o valor percentual da multa será de $15 \%$ (quinze por cento).

$\S 2^{\circ}$. No caso de ações coletivas movidas pelo Ministério Público do Trabalho, entidades sindicais ou em caso auto de infração lavrado por Auditor Fiscal do Trabalho, a multa será cobrada por trabalhador prejudicado e revertida ao Fundo de Amparo do Trabalhador.

Art. 14. Os contratos de prestação de serviços em vigor na data da vigência desta Lei terão o prazo de noventa dias, a contar de sua publicação, para se adequar às exigências nela contidas, exceto a estabelecida no artigo $4^{\circ}$.

Art. 15. Esta Lei entra em vigor na data de sua publicação.

\section{JUSTIFICATIVA}

Este Projeto de Lei tem como objetivo a definição da terceirização, assegurando a dignidade no trabalho. Com base nas experiências vividas pelos trabalhadores e dirigentes sindicais, é que a Central Única dos Trabalhadores elaborou algumas premissas que foram transformadas em proposições na forma deste Projeto de Lei.

No Brasil, não existe uma legislação específica que regule a terceirização. A Súmula 331 do TST é hoje a principal referência jurídica no assunto. A referida Súmula estabelece 
que a contratação de mão-de-obra por empresa interposta é ilegal, à exceção do trabalho temporário, serviço de vigilância, conservação/limpeza e os serviços especializados ligados à atividade-meio da tomadora. Entretanto, cabe dizer que as decisões judiciais são contraditórias quanto à sua interpretação.

Nos últimos anos, a terceirização tem avançado das atividades de apoio para áreas habitualmente relacionadas à atividade principal da empresa.

A suposta redução de custos tem sido acompanhada muitas vezes de diversos problemas trabalhistas, entre os quais: redução de postos de trabalho; redução de remuneração e benefícios, incremento de jornadas; insalubridade; aumento de acidentes de trabalho; redução fraudulenta de custos, com a subordinação direta e pessoal do empregado terceirizado à empresa contratante; ausência de responsabilidade subsidiária e solidária da empresa contratante, entre outros.

Tais premissas nos levam a concluir pela importância do Projeto de Lei ora apresentado. É sabido que a terceirização ao invés de proporcionar um bem, tem causado, em alguns casos, graves problemas no aspecto da qualidade e sobretudo nas condições de trabalho.

Nesse sentido é que nós acreditamos na sensibilidade e na responsabilidade dos parlamentares para que se cumpra a missão social do trabalho.

E essas são as razões pelas quais contamos com o apoio dos llustres Pares para a aprovação da presente proposição.

Sala das Sessões, em de julho de 2007.

\section{Deputado Vicentinho}

PT-SP 